\title{
OPEN Wells-Dawson phosphotungstates as mushroom tyrosinase inhibitors: a speciation study
}

\author{
Raphael Lampl(101, Joscha Breibeck ${ }^{\circledR 1}{ }^{1}$, Nadiia I. Gumerova ${ }^{(1}{ }^{1}$, Mathea Sophia Galanski ${ }^{2}{ }^{2}$ \& \\ Annette Rompel ${ }^{1} 1 \bowtie$
}

In order to elucidate the active polyoxotungstate (POT) species that inhibit fungal polyphenol oxidase (AbPPO4) in sodium citrate buffer at $\mathrm{pH} 6.8$, four Wells-Dawson phosphotungstates $[\alpha / \mathrm{B}$ $\left.\mathrm{P}_{2}^{\mathrm{V}} \mathrm{W}^{\mathrm{VI}}{ }_{18} \mathrm{O}_{62}\right]^{6-}$ (intact form), $\left[\alpha_{2}-\mathrm{P}_{2}{ }_{2} \mathrm{~W}^{\mathrm{VI}}{ }_{17} \mathrm{O}_{61}\right]^{10-}$ (monolacunary), $\left[\mathrm{PV}_{2}^{\mathrm{V}} \mathrm{W}^{\mathrm{VI}}{ }_{15} \mathrm{O}_{56}\right]^{12-}$ (trilacunary) and $\left[\mathrm{H}_{2} \mathrm{PV}_{2} \mathrm{WV}_{12} \mathrm{O}_{48}\right]^{12-}$ (hexalacunary) were investigated. The speciation of the POT solutions under the dopachrome assay ( $50 \mathrm{mM} \mathrm{Na}$-citrate buffer, $\mathrm{pH} 6.8 ; L-3,4$-dihydroxyphenylalanine as a substrate) conditions were determined by ${ }^{183} \mathrm{~W}$-NMR, ${ }^{31} \mathrm{P}-\mathrm{NMR}$ spectroscopy and mass spectrometry. The intact Wells-Dawson POT $\left[\alpha / 6-\mathrm{PV}_{2} \mathrm{WV}_{18}{ }_{18} \mathrm{O}_{62}\right]^{6-}$ shows partial ( 69\%) disintegration into the monolacunary $\left[\alpha_{2}-\mathrm{PV}_{2} \mathrm{WV}_{17} \mathrm{O}_{61}\right]^{10-}$ anion with moderate activity $\left(K_{i}=9.7 \mathrm{mM}\right)$. The monolacunary $\left[\alpha_{2}-\mathrm{PV}_{2} \mathrm{~W}^{\mathrm{VI}}{ }_{17} \mathrm{O}_{61}\right]^{10-}$ retains its structural integrity and exhibits the strongest inhibition of $A b P P O 4\left(K_{i}=6.5 \mathrm{mM}\right)$. The trilacunary POT $\left[\mathrm{PV}_{2} \mathrm{~W}_{15}^{\mathrm{VI}} \mathrm{O}_{56}\right]^{12-}$ rearranges to the more stable monolacunary $\left[\alpha_{2}-\mathrm{PV}_{2} \mathrm{~W}_{17}^{\mathrm{VI}} \mathrm{O}_{61}\right]^{10-}$ $(\sim 62 \%)$ accompanied by release of free phosphates and shows the weakest inhibition $\left(K_{i}=13.6 \mathrm{mM}\right)$. The hexalacunary anion $\left[\mathrm{H}_{2} \mathrm{PV}_{2} \mathrm{WV}_{12} \mathrm{O}_{48}\right]^{12-}$ undergoes time-dependent hydrolysis resulting in a mixture of $\left[\mathrm{H}_{2} \mathrm{PV}_{2} \mathrm{~W}^{\mathrm{V}}{ }_{12} \mathrm{O}_{48}\right]^{12-},\left[\mathrm{PV}_{8} \mathrm{~W}_{48}^{\mathrm{V}}{ }_{48} \mathrm{O}_{184}\right]^{40-},\left[\mathrm{PV}_{2} \mathrm{~W}^{\mathrm{Vl}}{ }_{19} \mathrm{O}_{69}\left(\mathrm{H}_{2} \mathrm{O}\right)\right]^{14-}$ and $\left[\alpha_{2}-\mathrm{PV}_{2} \mathrm{~W}^{\mathrm{VI}}{ }_{17} \mathrm{O}_{61}\right]^{10-}$ which together leads to comparable inhibitory activity $\left(K_{i}=7.5 \mathrm{mM}\right)$ after $48 \mathrm{~h}$. For the solutions of $\left[\alpha / B-\mathrm{PV}_{2} \mathrm{~W}_{18}^{\mathrm{VI}} \mathrm{O}_{62}\right]^{6-},\left[\alpha_{2}-\mathrm{PV}_{2} \mathrm{~W}^{\mathrm{VI}}{ }_{17} \mathrm{O}_{61}\right]^{10-}$ and $\left[\mathrm{PV}_{2}^{\mathrm{V}} \mathrm{WV}_{15}^{\mathrm{VV}} \mathrm{O}_{56}\right]^{12-}$ the inhibitory activity is correlated to the degree of their rearrangement to $\left[\alpha_{2}-\mathrm{PV}_{2} \mathrm{~W}^{\mathrm{VI}_{17}} \mathrm{O}_{61}\right]^{10-}$. The rearrangement of hexalacunary $\left[\mathrm{H}_{2} \mathrm{PV}_{2} \mathrm{WV}_{12} \mathrm{O}_{48}\right]^{12-}$ into at least four POTs with a negligible amount of monolacunary anion interferes with the correlation of activity to the degree of their rearrangement to $\left[\alpha_{2}-\mathrm{P}_{2}{ }_{2} \mathrm{~W}^{\mathrm{V}}{ }_{17} \mathrm{O}_{61}\right]^{10-}$. The good inhibitory effect of the Wells-Dawson $\left[\alpha_{2}-\mathrm{PV}_{2} \mathrm{~W}_{17} \mathrm{~V}_{17} \mathrm{O}_{61}\right]^{10-}$ anion is explained by the low charge density of its protonated forms $\mathrm{H}_{x}\left[\alpha_{2}-\mathrm{PV}_{2} \mathrm{WV}_{17}{ }_{17} \mathrm{O}_{61}\right]^{(10-x)-}(x=3$ or 4$)$ at $\mathrm{pH} 6.8$.

Polyphenol oxidases (PPOs) are copper-containing proteins omnipresent in animals, fungi, plants and bacteria ${ }^{1-5}$, with tyrosinases and catechol oxidases being prominent members of this enzyme family. Tyrosinases exhibit cresolase activity (EC 1.14.18.1; ortho-hydroxylation of monophenols to ortho-diphenols, monophenolase activity) and catecholase activity (EC 1.10.3.1; oxidation of ortho-diphenols to ortho-quinones; diphenolase activity), give rise to the rate determining step in melanogenesis and are involved in pigment coating and browning ${ }^{6}$. For its negligible lag phase and generally higher reaction velocity, the diphenolase activity of tyrosinases is usually assayed using $L$-DOPA ( $L-3,4$-dihydroxyphenylalanine, Figure S1A), as the substrate for the dopachrome assay ${ }^{7}$. The polyoxotungstate (POT) inhibition parameters were determined by fitting the kinetic data to a generalized Michaelis-Menten ${ }^{8}$ model and Lineweaver-Burk plots ${ }^{9}$, accompanied by POT speciation studies applying ${ }^{31} \mathrm{P}-$ NMR and ${ }^{183} \mathrm{~W}$-NMR spectroscopy and mass spectrometry under physiological conditions (50 mM Na-citrate buffer, $\mathrm{pH}$ 6.8) with or without the substrate $L$-DOPA. A good mushroom PPO inhibitor is the structurally related kojic acid (Fig. S1B), which holds inhibition constant $\left(K_{i}\right)$-values in the $\mu \mathrm{M}$ range ${ }^{10}$ and acts as a competitive inhibitor. ${ }^{10}$ Mushroom (Agaricus bisporus; abbr: $A b$ ) PPO is present in great quantity in fruiting bodies ${ }^{11}$. The enzyme has been thoroughly characterized in its structure ${ }^{12,13}$ and activity ${ }^{14}$. Following the established protocol by Pretzler et al. ${ }^{15}, A b$ PPO4 was recombinantly expressed in E. coli and purified in its active form for the here presented inhibition studies.

Polyoxometalates (POMs) are metal-oxygen clusters commonly built up by W, Mo or V addenda ions, which are usually in their highest oxidation states exhibiting the electronic configuration $\mathrm{d}^{0}$ or $\mathrm{d}^{116,17}$. POMs show a widespread biological applicability such as antibacterial ${ }^{18}$ and anti-tumor activity ${ }^{19}$, and stable POTs have

${ }^{1}$ Fakultät für Chemie, Institut für Biophysikalische Chemie, Universität Wien, Althanstraße 14, 1090 Wien, Austria. ${ }^{2}$ Fakultät für Chemie, Institut für Anorganische Chemie und NMR Zentrum, Universität Wien, Währinger Str. 42, 1090 Wien, Austria. ${ }^{\square}$ email: annette.rompel@univie.ac.at 

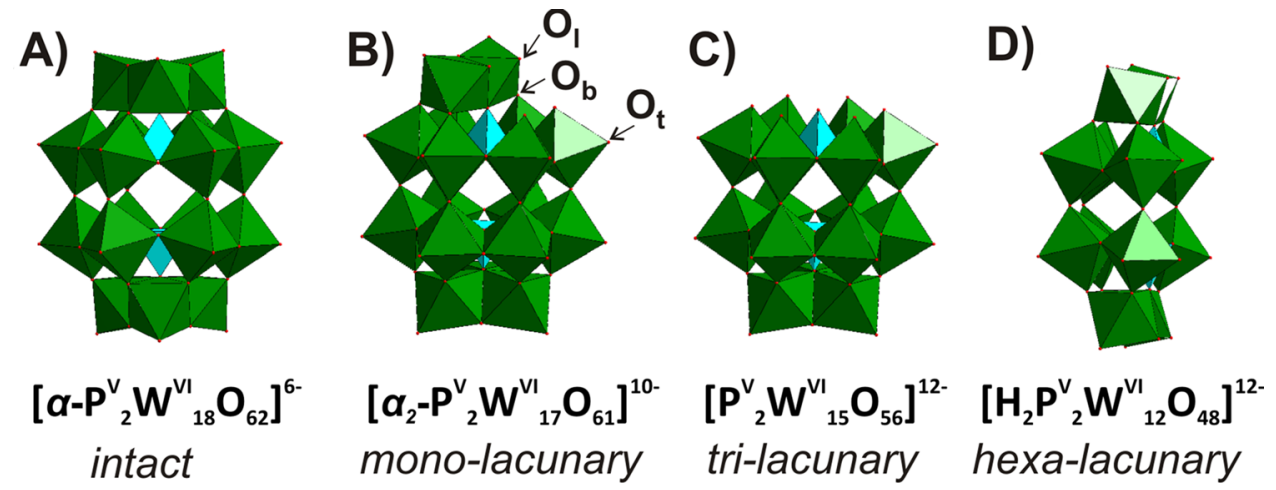

Figure 1. The POTs (A-D) feature the Wells-Dawson archetype and they are derived from the $\alpha$-isomer of $\left[\mathrm{P}_{2}{ }_{2} \mathrm{~W}^{\mathrm{VI}}{ }_{18} \mathrm{O}_{62}\right]^{6-}$. Three types of oxygen atoms $\left(\mathrm{O}_{\mathrm{t}}\right.$-terminal, $\mathrm{O}_{\mathrm{b}}$ - bridging, $\mathrm{O}_{1}$-surrounding the lacuna $)$ are exemplified in (B). Color code: $\left\{\mathrm{WO}_{6}\right\}$ octahedra, green; $\left\{\mathrm{PO}_{4}\right\}$ tetrahedra, turquoise.

successfully been applied as additives in co-crystallization experiments with proteins ${ }^{20-24}$. Apart from the Anderson-Evans archetype ${ }^{25}$ (e.g. $\left[\mathrm{Te}^{\mathrm{VI}} \mathrm{W}_{6}^{\mathrm{VI}} \mathrm{O}_{24}\right]^{6-}$ is stable in aqueous solution between pH 4.5 and 7.5) most POTs show low stability at physiological conditions, requiring solution NMR-measurements to reveal the composition under the applied conditions. As POTs possess a higher chemical stability than polyoxomolybdates (POMos), tungsten is usually selected as the addenda ion, when applying this compound class in biological investigations ${ }^{26}$.

Recently, a systematic approach varying the charge density in a series of Keggin POTs was reported by Breibeck et al. ${ }^{27}$ to characterize their inhibitory effects against recombinant $A b P P O 4{ }^{15}$. A detailed assignment of the active Keggin POT species was undertaken applying NMR spectroscopy ${ }^{27}$. A charge density dependence of the inhibitory capacities was derived, where the most active Keggin POT was $\left[\mathrm{Si}^{\mathrm{IV}} \mathrm{W}^{\mathrm{VI}}{ }_{12} \mathrm{O}_{40}\right]^{4-}\left(K_{i}=4.7 \mathrm{mM}\right)$, and the more stable Keggin anions with higher charge density did not inhibit diphenolase activity.

Another prominent POM scaffold investigated for biological activity is the Wells-Dawson archetype with the general formula $\left[\left(\mathrm{X}^{n+}\right)_{2} \mathrm{M}_{18} \mathrm{O}_{62}\right]^{(16-2 n)-28}$, where $\mathrm{M}$ is either $\mathrm{W}^{\mathrm{VI}}$ or $\mathrm{Mo}^{\mathrm{VI}}$ and $\mathrm{X}^{n+}$ is commonly phosphorus $(\mathrm{V})$ or arsenic $(\mathrm{V})$. For the intact form of this cluster, $18\left\{\mathrm{MO}_{6}\right\}$ octahedral units enclose both inner heteroion groups $\left\{\mathrm{XO}_{4}\right\}$ by corner- and edge-sharing (Fig. 1). Wells-Dawson POMs exhibited antibacterial ${ }^{29}$ activity, and both the intact anion $\left[\alpha / \beta-\mathrm{P}_{2}{ }_{2} \mathrm{~W}^{\mathrm{VI}}{ }_{18} \mathrm{O}_{62}\right]^{6-}$ and the hexalacunary form $\left[\mathrm{H}_{2} \mathrm{P}^{\mathrm{V}}{ }_{2} \mathrm{~W}^{\mathrm{VI}}{ }_{12} \mathrm{O}_{48}\right]^{12-}$ inhibited $\mathrm{Ca}^{2+}$-ATPase, P-type ATPase $^{30}$, and aquaporin- $3^{31}$. Transition metal-substituted Wells-Dawson POMos were used as inhibitors against a-glucosidase ${ }^{32}$ with $K_{i}$-values covering a wide range down to the $\mu \mathrm{M}$ scale.

In this study, the inhibitory effect of four structurally related Wells-Dawson POTs, intact $\mathrm{Cat}_{6}\left[\alpha / \beta-\mathrm{P}_{2}{ }_{2} \mathrm{~W}^{\mathrm{VI}}{ }_{18} \mathrm{O}_{62}\right] \cdot 14 \mathrm{H}_{2} \mathrm{O}\left(\mathrm{Cat}=\mathrm{K}^{+}, \mathrm{NH}_{4}^{+}\right)^{33,34}$, mono-lacunary $\mathrm{K}_{10}\left[\alpha_{2}-\mathrm{P}_{2}{ }_{2} \mathrm{~W}^{\mathrm{VI}}{ }_{17} \mathrm{O}_{61}\right] \cdot 20 \mathrm{H}_{2} \mathrm{O}^{34,35}$, trilacunary $\mathrm{K}_{12}\left[\mathrm{P}_{2}{ }_{2} \mathrm{~W}^{\mathrm{VI}}{ }_{15} \mathrm{O}_{56}\right] \cdot 24 \mathrm{H}_{2} \mathrm{O}^{35,36}$ and hexalacunary $\left(\mathrm{NH}_{4}\right)_{12}\left[\mathrm{H}_{2} \mathrm{P}^{\mathrm{V}}{ }_{2} \mathrm{WVI}_{12} \mathrm{O}_{48}\right] \cdot 24 \mathrm{H}_{2} \mathrm{O}^{37,38}$, with net charges from 6 - to $12-$ (Fig. 1 ) on the catecholase activity of $A b P P O 4$ is explored. The focus is on the identification of the active species present under the diphenolase activity assay conditions by NMR spectroscopy and mass spectrometry. For the inhibition studies, the POTs were buffered at $\mathrm{pH} 6.8$ in $50 \mathrm{mM}$ Na-citrate and the obtained solutions are termed $\left[\mathrm{P}_{2} \mathbf{W}_{18}\right]^{6-}$ for $\mathrm{K}_{6}\left[\alpha / \beta-\mathrm{P}_{2}{ }_{2} \mathrm{~W}^{\mathrm{VI}}{ }_{18} \mathrm{O}_{62}\right] \cdot 14 \mathrm{H}_{2} \mathrm{O}$ and $\left(\mathrm{NH}_{4}\right)_{6}\left[\alpha / \beta-\mathrm{P}_{2} \mathrm{~W}^{\mathrm{VI}}{ }_{18} \mathrm{O}_{62}\right] \cdot 14 \mathrm{H}_{2} \mathrm{O}$, $\left[\mathbf{P}_{2} \mathbf{W}_{17}\right]^{10-}$ for $\mathrm{K}_{10}\left[\alpha_{2}-\mathrm{P}_{2}{ }_{2} \mathrm{~W}^{\mathrm{VI}}{ }_{17} \mathrm{O}_{61}\right] \cdot 20 \mathrm{H}_{2} \mathrm{O},\left[\mathbf{P}_{2} \mathbf{W}_{15}\right]^{12-}$ for $\mathrm{K}_{12}\left[\mathrm{P}_{2}{ }_{2} \mathrm{~W}^{\mathrm{VI}}{ }_{15} \mathrm{O}_{56}\right] \cdot 24 \mathrm{H}_{2} \mathrm{O}$ and $\left[\mathbf{P}_{2} \mathbf{W}_{12}\right]^{12-}$ for $\left(\mathrm{NH}_{4}\right)_{12}\left[\mathrm{H}_{2} \mathrm{P}_{2}{ }_{2} \mathrm{~W}_{12}^{\mathrm{VI}} \mathrm{O}_{48}\right] \cdot 24 \mathrm{H}_{2} \mathrm{O}$ to distinguish the buffered solution sample from the solid compound (see Abbreviation section in SI).

\section{Results and discussion}

Activity plots of AbPPO4 inhibited by Wells-Dawson POTs. AbPPO4 was purified and activated according to Pretzler et al. ${ }^{15}$. The ESI-MS of active AbPPO4 is presented in Fig. S2 and Table S1, the protein sequence of AbPPO4 in Fig. S3 and the SDS-PAGE analysis of AbPPO4 is shown in Figs. S4 and S5. The protocols for the synthesis of the Wells-Dawson POTs were taken from published procedures (cf. Table S2) and their identity was confirmed by IR (Fig. S6, Table S3) in the solid state and by ${ }^{31} \mathrm{P}-$ and ${ }^{183} \mathrm{~W}-\mathrm{NMR}$ in solutions (Figs. S7-S13). To investigate the Wells-Dawson POT-mediated inhibition of AbPPO4, the corresponding POT $\left(\left[\mathbf{P}_{2} \mathbf{W}_{18}\right]^{6-},\left[\mathbf{P}_{\mathbf{2}} \mathbf{W}_{17}\right]^{10-},\left[\mathbf{P}_{\mathbf{2}} \mathbf{W}_{15}\right]^{12-},\left[\mathbf{P}_{2} \mathbf{W}_{12}\right]^{12-}\right)$ was dissolved in $50 \mathrm{mM} \mathrm{Na-citrate} \mathrm{buffer} \mathrm{(pH} \mathrm{6.8),} \mathrm{where}$ the enzyme shows its maximal activity ${ }^{4,15}$. The diphenolase activity of tyrosinase was monitored using $1 \mathrm{mM}$ $L$-DOPA (Fig. S1A) as the substrate. Considering that the Wells-Dawson POT stability is $\mathrm{pH}$ and possibly time dependent, a speciation study was performed which is detailed in the paragraph "Speciation of Wells-Dawson POT by ${ }^{183} \mathrm{~W}-\mathrm{NMR}$ and ${ }^{31} \mathrm{P}-\mathrm{NMR}$ analyses at $\mathrm{pH} 6.8$. The concentration of the investigated Wells-Dawson phosphotungstates was in the range between 0 and $5 \mathrm{mM}$. If enzymatic inhibition was observed, data were taken in triplicates and fitted with a hyperbolic function (cf. SI Eq. (5)) from a mixed inhibition model to evaluate the $K_{i}$ and $\alpha$-parameters. All four solutions $\left[\mathbf{P}_{2} \mathbf{W}_{18}\right]^{6-},\left[\mathbf{P}_{2} \mathbf{W}_{17}\right]^{10-},\left[\mathbf{P}_{2} \mathbf{W}_{15}\right]^{12-}$ and $\left[\mathbf{P}_{2} \mathbf{W}_{12}\right]^{12-}$ showed a mixedtype inhibition with $K_{i}$ values in the $\mathrm{mM}$ range, binding both to the free enzyme and to the enzyme-substrate complex $^{39}$ (Table 1, Fig. 2). As a positive control for the inhibition of AbPPO4 diphenolase activity and for validation of the kinetic methodology, the well-characterized natural PPO-inhibitor kojic acid ${ }^{10}$ (Fig. S1B) was additionally tested and evaluated applying exactly the same mathematical model. The organic inhibitor kojic 


\begin{tabular}{|l|l|l|l|l|}
\hline Inhibitor & $\boldsymbol{K}_{\boldsymbol{i}}[\mathrm{mM}]$ & $\boldsymbol{\alpha}$ & $\mathbf{R}^{2}$ & Inhibition type \\
\hline$\left[\mathbf{P}_{2} \mathbf{W}_{18}\right]^{6-}$ & $9.7^{\mathrm{a}}, 13.0^{\mathrm{b}}$ & $0.013^{\mathrm{a}}, 0.22^{\mathrm{b}}$ & 0.80 & Mixed-type \\
\hline$\left[\mathbf{P}_{2} \mathbf{W}_{17}\right]^{10-}$ & $6.5^{\mathrm{a}}, 10.6^{\mathrm{b}}$ & $0.01^{\mathrm{a}}, 0.01^{\mathrm{b}}$ & 0.93 & Mixed-type \\
\hline$\left[\mathbf{P}_{2} \mathbf{W}_{15}\right]^{12-}$ & $13.6^{\mathrm{a}}, 10.7^{\mathrm{b}}$ & $0.003^{\mathrm{a}}, 0.20^{\mathrm{b}}$ & 0.96 & Mixed-type \\
\hline$\left[\mathbf{P}_{2} \mathbf{W}_{12}\right]^{12-}$ & $7.5^{\mathrm{a}}, 5.6^{\mathrm{b}}$ & $0.017^{\mathrm{a}}, 0.28^{\mathrm{b}}$ & 0.91 & Mixed-type \\
\hline Control: kojic acid ${ }^{10}$ & $4.5 \cdot 10^{-3 \mathrm{a}}, 4.3 \cdot 10^{-3 \mathrm{~b}}$ & $2.6 \times 10^{15}$ & 1.0 & Competitive \\
\hline
\end{tabular}

Table 1. Summary of kinetic evaluation of AbPPO4 inhibition by Wells-Dawson POTs. $K_{i}$ : inhibition constant. $\alpha$ : inhibition parameter, $\mathrm{R}^{2}$ : curve fit determination coefficient; the parameters were determined ${ }^{a}$ from activity plot and ${ }^{b}$ from the Lineweaver-Burk slopes or intercepts. For comparison, the results for the Keggin series are provided $\mathrm{in}^{27}$.

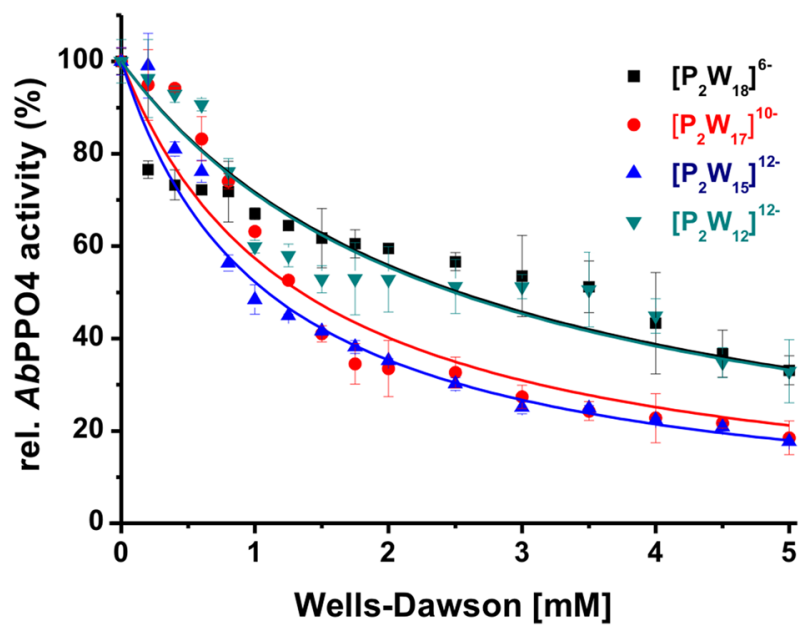

Figure 2. Activity plots of $A b \mathrm{PPO} 4$ with four Wells-Dawson phosphotungstates $\left[\mathbf{P}_{\mathbf{2}} \mathbf{W}_{18}\right]^{6-},\left[\mathbf{P}_{\mathbf{2}} \mathbf{W}_{17}\right]^{10-}$, $\left[\mathbf{P}_{2} \mathbf{W}_{15}\right]^{12-}$ and $\left[\mathbf{P}_{2} \mathbf{W}_{12}\right]^{12-}$. The dopachrome assay was performed using $1 \mathrm{mM} \mathrm{L}$-DOPA as the substrate in $50 \mathrm{mM} \mathrm{Na}$-citrate buffer at $\mathrm{pH}$ 6.8. The measurements were taken in triplicates and a hyperbolic curve fit (Eq. (5), SI) was performed. The kinetic inhibition parameters are summarized in Table 1.

acid features a $K_{i}$ in the $\mu \mathrm{M}$ range corresponding to a much higher affinity to the enzyme as revealed for the Wells-Dawson POTs. The $K_{i}$ values previously reported for Keggin POTs $\left[\mathrm{XW}^{\mathrm{VI}}{ }_{12} \mathrm{O}_{40}\right]^{\mathrm{n}-}\left(\mathrm{X}=\mathrm{P}^{\mathrm{V}}, \mathrm{Si}^{\mathrm{IV}}, \mathrm{B}^{\mathrm{III}}, \mathrm{A}^{\mathrm{III}}\right.$, $\left.\mathrm{H}_{2}^{2+}, \mathrm{Be}^{\mathrm{II}}\right)$, which were obtained under the same conditions, are also in the $\mathrm{mM}$ range and vary from $4.7 \mathrm{mM}$ $\left(\mathrm{X}=\mathrm{Si}^{\mathrm{IV}}\right)$ to $25.6 \mathrm{mM}\left(\mathrm{X}=\mathrm{P}^{\mathrm{V}}\right)^{27}$. The $K_{i}$ values obtained using the Michaelis-Menten model, which is the generally accepted method for calculating the enzyme kinetic parameters, are used as primary values to compare the POTs' activities.

To evaluate the inhibitory effect, the activity curves for four Wells-Dawson phosphotungstates were plotted in the concentration range $0-5 \mathrm{mM}$ (Fig. 2). Among the Wells-Dawson clusters, $\left[\mathbf{P}_{2} \mathbf{W}_{17}\right]^{10-}$ showed the greatest inhibitory effect $\left(K_{i}=6.5 \mathrm{mM}\right)$ and the fitted $\alpha$-parameter suggests a mixed mode of inhibition (Table 1). According to their $K_{i}$ values $\left[\mathbf{P}_{2} \mathbf{W}_{17}\right]^{10-}\left(K_{i}=6.5 \mathrm{mM}\right)$ and $\left[\mathbf{P}_{2} \mathbf{W}_{12}\right]^{12-}\left(K_{i}=7.5 \mathrm{mM}\right)$ exhibited nearly identical inhibitory activity and $\left[\mathbf{P}_{2} \mathbf{W}_{18}\right]^{6-}\left(K_{i}=9.7 \mathrm{mM}\right)$ and $\left[\mathbf{P}_{2} \mathbf{W}_{15}\right]^{12-}\left(K_{i}=13.6 \mathrm{mM}\right)$ showed a lower inhibition capacity.

Lineweaver-Burk evaluation of inhibition types. The type of enzymatic inhibition is usually investigated by linear plots according to Lineweaver-Burk, also allowing for further validation of the inhibitory constant $K_{i}{ }^{9}$ For $\left[\mathbf{P}_{2} \mathbf{W}_{18}\right]^{6-},\left[\mathbf{P}_{2} \mathbf{W}_{17}\right]^{10-},\left[\mathbf{P}_{2} \mathbf{W}_{15}\right]^{12-}$ and $\left[\mathbf{P}_{2} \mathbf{W}_{12}\right]^{12-}$ as well as for the kojic acid control measured in our previous study ${ }^{27}$, the dopachrome assay was repeated at five different substrate concentrations (varying from 0.4 to $1.5 \mathrm{mM}$ ) and three different inhibitor concentrations, respectively (SI section 7, Figs. S14-S17, Tables S4, S5). Each POT analysis yielded a set of three lines intersecting in a common point. The slopes (SI Eq. (13), insets in Figs. S14-S17) and ordinate intercepts of these regression lines were further evaluated to validate the inhibitory constant $K_{i}$ and the a-parameter from the non-linear regression procedure. Therefore, the slopes were plotted against the used inhibitor concentrations to give lines intersecting the abscissa at $-K_{i}$. Similarly, the Lineweaver-Burk ordinate intercepts were evaluated for the a-parameter (cf. Table S5 and Table 1). In good accordance with their structural similarity, the respective intersection point of the three Lineweaver-Burk lines is the third quadrant for all four Wells-Dawson POT solutions $\left[\mathbf{P}_{2} \mathbf{W}_{18}\right]^{6-},\left[\mathbf{P}_{2} \mathbf{W}_{17}\right]^{10-},\left[\mathbf{P}_{2} \mathbf{W}_{15}\right]^{12-}$ and $\left[\mathbf{P}_{2} \mathbf{W}_{12}\right]^{12-}$, which indicated mixed-type inhibition ${ }^{39,40}$ previously found for POT representatives of the Keggin archetype ${ }^{27}$. 
(1)

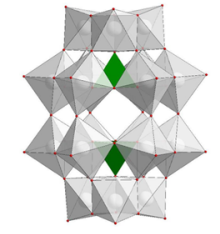

$\left.\alpha-\mathrm{P}_{2} \mathbf{W}_{18} \mathrm{O}_{62}\right]^{6-}$

(2)

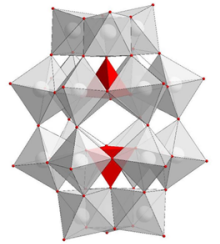

$\left[\beta-P_{2} W_{18} O_{62}\right]^{6-}$

(3)

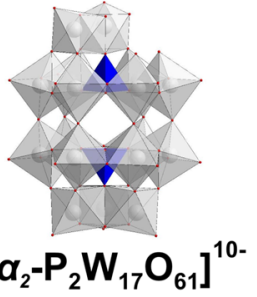

(4)
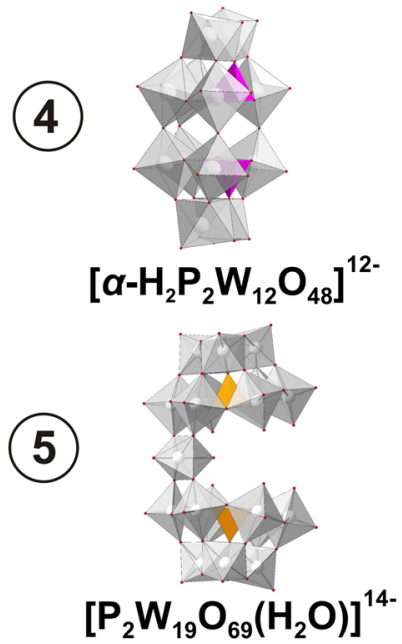

(6)

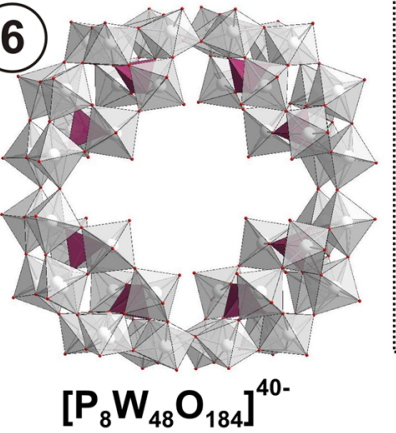

A) $\left[P_{2} W_{18}\right]^{6-}$

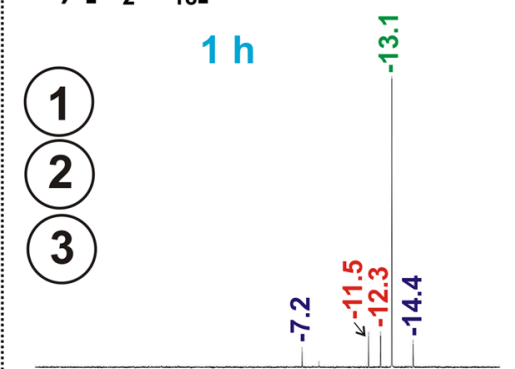

(3) $48 \mathrm{~h}$

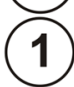

(2)

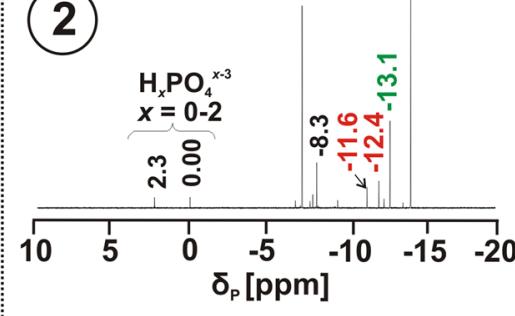

\section{C) $\left[P_{2} W_{15}\right]^{12}$}

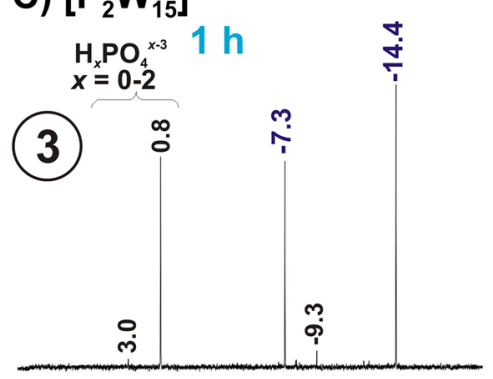

D) $\left[P_{2} W_{12}\right]^{12-}$

B) $\left[P_{2} W_{17}\right]^{10 \text { - }}$

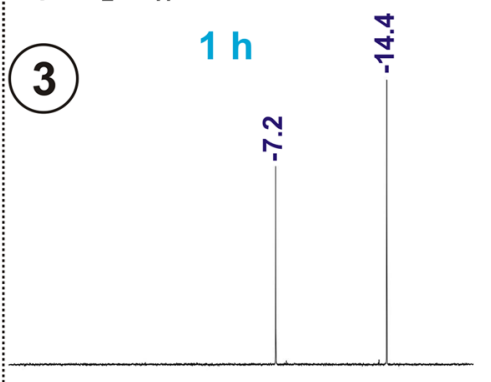

3

$48 \mathrm{~h}$

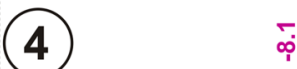

(3)

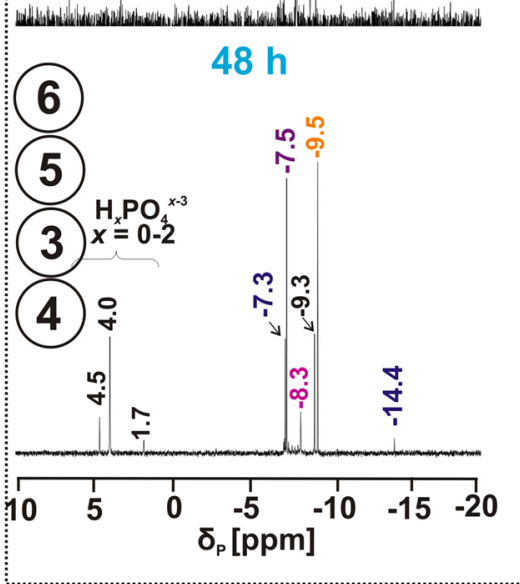

Figure 3. ${ }^{31} \mathrm{P}-\mathrm{NMR}$ spectra of $\left[\mathbf{P}_{2} \mathbf{W}_{18}\right]^{6-},\left[\mathbf{P}_{2} \mathbf{W}_{17}\right]^{10-},\left[\mathbf{P}_{2} \mathbf{W}_{15}\right]^{12-}$ and $\left[\mathbf{P}_{2} \mathbf{W}_{12}\right]^{12-}$ in $50 \mathrm{mM}$ Na-citrate buffer at $\mathrm{pH} 6.8$ (Table S2) recorded $1 \mathrm{~h}$ and $48 \mathrm{~h}$ after preparation. A) educts: $\left[\alpha-\mathrm{PV}_{2} \mathrm{~W}^{\mathrm{VI}}{ }_{18} \mathrm{O}_{62}\right]^{6-}$ and $\left[\beta-\mathrm{P}_{2}{ }_{2} \mathrm{~W}_{18}^{\mathrm{VI}} \mathrm{O}_{62}\right]^{6-} ;$ products: fresh $-\left[\alpha / \beta-\mathrm{P}_{2} \mathrm{~W}^{\mathrm{VI}}{ }_{18} \mathrm{O}_{62}\right]^{6-}$ $(88 \%)$ and $\left[\alpha_{2}-\mathrm{P}^{\mathrm{V}}{ }_{2} \mathrm{~W}^{\mathrm{VI}}{ }_{17} \mathrm{O}_{61}\right]^{10-}(12 \%)$, after $48 h-\left[\alpha / \beta-\mathrm{P}_{2} \mathrm{~W}^{\mathrm{VI}}{ }_{18} \mathrm{O}_{62}\right]^{6-}(15 \%)$ and $\left.\left[\alpha_{2}-\mathrm{PV}_{2}{ }_{2} \mathrm{~W}^{\mathrm{VI}}{ }_{17} \mathrm{O}_{61}\right]^{10-}(69 \%) ; \mathrm{B}\right)$ educt $\left[\alpha_{2}{ }^{-}\right.$ $\left.\mathrm{P}_{2}{ }_{2} \mathrm{~W}_{17}{ }_{17} \mathrm{O}_{61}\right]^{10-} ;$ products: fresh- $\left[\alpha_{2}-\mathrm{P}_{2}{ }_{2} \mathrm{~W}^{\mathrm{VI}}{ }_{17} \mathrm{O}_{61}\right]^{10-}(100 \%)$, after $48 h-\left[\alpha_{2}-\mathrm{PV}_{2} \mathrm{~W}^{\mathrm{VI}}{ }_{17} \mathrm{O}_{61}\right]^{10-}(92 \%)$; C) educt: $\left[\mathrm{PV}_{2} \mathrm{~W}^{\mathrm{VI}}{ }_{15} \mathrm{O}_{56}\right]^{12-}$; products: fresh $-\left[\alpha_{2}-\mathrm{P}_{2}{ }_{2} \mathrm{~W}^{\mathrm{VI}}{ }_{17} \mathrm{O}_{61}\right]^{10-}(62 \%)$, after $48 h-\left[\alpha_{2}-\mathrm{P}_{2}{ }_{2} \mathrm{~W}^{\mathrm{VI}}{ }_{17} \mathrm{O}_{61}\right]^{10-}(61 \%)$; D) educt: $\left[\mathrm{H}_{2} \mathrm{P}_{2}{ }_{2} \mathrm{WVI}_{12}^{\mathrm{VI}} \mathrm{O}_{48}\right]^{12-} ;$ products: fresh- $\left[\mathrm{H}_{2} \mathrm{P}_{2}{ }_{2} \mathrm{~W}^{\mathrm{VI}}{ }_{12} \mathrm{O}_{48}\right]^{12-}(72 \%),\left[\alpha_{2}-\mathrm{P}_{2}{ }_{2} \mathrm{~W}^{\mathrm{VI}}{ }_{17} \mathrm{O}_{61}\right]^{10-}(20 \%)$, after $48 \mathrm{~h}-\left[\mathrm{P}_{8} \mathrm{VW}^{\mathrm{VI}}{ }_{48} \mathrm{O}_{184}\right]^{40-}(23 \%),\left[\mathrm{P}_{2}{ }_{2} \mathrm{~W}^{\mathrm{V}}{ }_{19} \mathrm{O}_{69}\left(\mathrm{H}_{2} \mathrm{O}\right)\right]^{14-}(22 \%)$, $\left[\mathrm{H}_{2} \mathrm{P}_{2}{ }_{2} \mathrm{~W}^{\mathrm{VI}}{ }_{12} \mathrm{O}_{48}\right]^{12-}(9 \%),\left[\alpha_{2}-\mathrm{P}_{2}{ }_{2} \mathrm{~W}^{\mathrm{VI}}{ }_{17} \mathrm{O}_{61}\right]^{10-}(3 \%)$. Weak signals in the range between -10 and $-7 \mathrm{ppm}$ correspond to unstable solution intermediates with a total of $9 \%$ for $\left[\mathbf{P}_{2} \mathbf{W}_{18}\right]^{6-}(\mathbf{A}) ; 8 \%$ for $\left[\mathbf{P}_{2} \mathbf{W}_{17}\right]^{10-}(\mathbf{B}) ; 5 \%$ for $\left[\mathbf{P}_{2} \mathbf{W}_{15}\right]^{12-}(\mathbf{C})$ and $19 \%$ for $\left[\mathbf{P}_{2} \mathbf{W}_{12}\right]^{12-}(\mathbf{D})$ in aged solutions based on integrated POT signals ${ }^{34,41,44}$, Signal assignment is based on references ${ }^{34,37,41}$. Color code: $\left\{\mathrm{WO}_{6}\right\}$ octahedra, white; $\left\{\mathrm{PO}_{4}\right\}$ tetrahedra, green, red, blue, pink, orange, burgundy; $\mathrm{O}$ atoms, red. 


\begin{tabular}{|c|c|c|c|c|}
\hline Educt POT & $\begin{array}{l}\text { Charge } \\
\text { density } q / m \text { of } \\
\text { POT educt }\end{array}$ & \begin{tabular}{|l|} 
Stable in \\
Na-citrate \\
buffer at pH 6.8
\end{tabular} & Dominant POT species at pH 6.8 in Na-citrate buffer & $\begin{array}{l}\text { Charge density } q / m \text { of POT } \\
\text { product }\end{array}$ \\
\hline$\left[\alpha / \beta-\mathrm{P}_{2}{ }_{2} \mathrm{~W}_{18}^{\mathrm{VI}} \mathrm{O}_{62}\right]^{6-}$ & 0.33 & No & $\mathrm{H}_{x}\left[\alpha_{2}-\mathrm{P}_{2}{ }_{2} \mathrm{~W}_{17}^{\mathrm{VI}} \mathrm{O}_{61}\right]^{(10-x)-}$ & 0.35 for $x=4$ and 0.41 for $x=3$ \\
\hline$\left[\alpha_{2}-\mathrm{PV}_{2} \mathrm{~W}_{17}^{\mathrm{VI}} \mathrm{O}_{61}\right]^{10-}$ & 0.59 & Yes & $\mathrm{H}_{x}\left[\alpha_{2}-\mathrm{P}_{2}{ }_{2} \mathrm{~W}_{17}^{\mathrm{VI}} \mathrm{O}_{61}\right]^{(10-x)-}$ & 0.35 for $x=4$ and 0.41 for $x=3$ \\
\hline$\left[\mathrm{P}_{2}{ }_{2} \mathrm{~W}_{15}^{\mathrm{VI}} \mathrm{O}_{56}\right]^{12-}$ & 0.8 & No & $\mathrm{H}_{x}\left[\alpha_{2}-\mathrm{PV}_{2}{ }_{2} \mathrm{~W}_{17}^{\mathrm{VI}_{17}} \mathrm{O}_{61}\right]^{(10-x)-}$ & 0.35 for $x=4$ and 0.41 for $x=3$ \\
\hline $\mathrm{H}_{2}\left[\mathrm{P}_{2}{ }_{2} \mathrm{~W}^{\mathrm{VI}}{ }_{12} \mathrm{O}_{48}\right]^{12-}$ & 1 & No & $\begin{array}{l}{\left[\mathrm{H}_{2} \mathrm{PV}_{2} \mathrm{WW}^{\mathrm{V}}\right.} \\
\left.{ }_{12} \mathrm{O}_{48}\right]^{12-}+\mathrm{H}_{x}\left[\alpha_{2}-\mathrm{P}_{2}{ }_{2} \mathrm{~W}_{17}^{\mathrm{VI}} \mathrm{O}_{61}\right]^{(10-x)-}+\left[\mathrm{PV}_{2}^{\mathrm{V}} \mathrm{W}_{19}^{\mathrm{VI}} \mathrm{O}_{69}\left(\mathrm{H}_{2} \mathrm{O}\right)\right]^{14-}+\left[\mathrm{PV}_{8}^{\mathrm{V}} \mathrm{W}_{48}^{\mathrm{VI}}{ }_{48} \mathrm{O}_{184}\right]^{40-}\end{array}$ & - \\
\hline
\end{tabular}

Table 2. Stability under physiological conditions and charge densities $(q / m)$ of $\left[\mathbf{P}_{2} \mathbf{W}_{18}\right]^{6-},\left[\mathbf{P}_{2} \mathbf{W}_{17}\right]^{10-}$, $\left[\mathbf{P}_{2} \mathbf{W}_{15}\right]^{12-}$ and $\left[\mathbf{P}_{2} \mathbf{W}_{12}\right]^{12-}$, with $\mathrm{H}_{x}\left[\alpha_{2}-\mathrm{P}_{2}{ }_{2} \mathrm{~W}^{\mathrm{VI}}{ }_{17} \mathrm{O}_{61}\right]^{(10-x)-}(\mathrm{x}=3$ or 4$)$.

Speciation of Wells-Dawson POT by ${ }^{183} \mathrm{~W}-\mathrm{NMR}$ and ${ }^{31} \mathrm{P}-\mathrm{NMR}$ analyses at pH 6.8. The detailed structural information about species under the respective experimental conditions is essential for understanding of POT activity ${ }^{17}$. All Wells-Dawson POTs were dissolved in reaction buffer (50 mM Na-citrate, $\mathrm{pH} 6.8$ ) and were adjusted with $1 \mathrm{M} \mathrm{HCl}$ or $1 \mathrm{M} \mathrm{NaOH}$ to $\mathrm{pH} 6.8$ for measurements with $\mathrm{AbPPO}$, where the enzyme shows its maximal activity ${ }^{4,15}$. Upon dissolution of $\left[\mathbf{P}_{2} \mathbf{W}_{18}\right]^{6-}$ and $\left[\mathbf{P}_{2} \mathbf{W}_{17}\right]^{10-}$, the $\mathrm{pH}$ of the buffer slightly decreased, whereas $\left[\mathbf{P}_{\mathbf{2}} \mathbf{W}_{15}\right]^{12-}$ and $\left[\mathbf{P}_{\mathbf{2}} \mathbf{W}_{12}\right]{ }^{12-}$ behaved as bases. ${ }^{31} \mathrm{P}-\mathrm{NMR}$ in combination with ${ }^{183} \mathrm{~W}-\mathrm{NMR}$ is established as a useful technique to determine the structural composition of the Wells-Dawson POTs ${ }^{16}$ and was previously successfully applied to elucidate the speciation of Keggin-type POTs in an analogous study ${ }^{27}$. The concentration of all species was calculated based on ${ }^{31} \mathrm{P}-\mathrm{NMR}$ peaks integration. Since the stock solutions of each Wells-Dawson POT was used up to three days after preparation and ${ }^{183} \mathrm{~W}$-NMR acquisition takes $60 \mathrm{~h},{ }^{31} \mathrm{P}$-NMR spectra for all four solutions have been recorded $1 \mathrm{~h}$ and $48 \mathrm{~h}$ after preparation to check if speciation changes occur over time. Under the experimental conditions $\left(50 \mathrm{mM} \mathrm{Na}\right.$-citrate, $\mathrm{pH}$ 6.8) $\left[\mathbf{P}_{\mathbf{2}} \mathbf{W}_{18}\right]^{6-}$ showed partial hydrolysis of intact $\left[\alpha / \beta-\mathrm{P}_{2}{ }_{2} \mathrm{~W}^{\mathrm{VI}}{ }_{18} \mathrm{O}_{62}\right]^{6-}$ (Fig. 1A) to monolacunary (Fig. 1B) $\left[\alpha_{2}-\mathrm{P}_{2}{ }_{2} \mathrm{~W}^{\mathrm{VI}}{ }_{17} \mathrm{O}_{61}\right]^{10-}$ (Figs. 3A, S8B). In the solution of intact POT one hour after preparation $12 \%$ of $\left[\alpha_{2}-\mathrm{P}_{2}{ }_{2} \mathrm{~W}^{\mathrm{VI}}{ }_{17} \mathrm{O}_{61}\right]^{10-}$ was detected based on ${ }^{31} \mathrm{P}$ NMR peaks integration (Fig. $3 \mathrm{~A}$ ), whereas $48 \mathrm{~h}$ after dissolution the concentration of monolacunary anion increased to $69 \%$. The ${ }^{183} \mathrm{~W}-\mathrm{NMR}$ spectrum of $\left[\mathbf{P}_{2} \mathbf{W}_{18}\right]^{6-}$ (Fig. S8B) is in agreement with ${ }^{31} \mathrm{P}-\mathrm{NMR}$ data and demonstrates 9 signals for the mono-lacunary anion and 6 additional signals related to a mixture of intact $[\alpha / \beta$ $\left.\mathrm{P}_{2} \mathrm{~W}^{\mathrm{VI}}{ }_{18} \mathrm{O}_{62}\right]^{6-}$ isomers. ${ }^{31} \mathrm{P}-\mathrm{NMR}$ studies showed that the solution of monolacunary POT $\left[\mathbf{P}_{2} \mathbf{W}_{17}\right]^{10-}$ exhibited $\left[\alpha_{2}-\mathrm{P}_{2}{ }_{2} \mathrm{~W}^{\mathrm{VI}}{ }_{17} \mathrm{O}_{61}\right]^{10-}$ as the only species present in the freshly prepared solution (Fig. $3 \mathrm{~B}$ ), and as the dominant anion $(92 \%)$ after $48 \mathrm{~h}$ of solution aging. The ${ }^{31} \mathrm{P}-\mathrm{NMR}$ spectrum of tri-lacunary POT $\left[\mathbf{P}_{2} \mathbf{W}_{15}\right]^{12-}($ Fig. $3 \mathrm{C})$ demonstrates the fast rearrangement of the tri-lacunary anion to $62 \%$ of monolacunary $\left[\alpha_{2}-\mathrm{P}_{2}{ }_{2} \mathrm{~W}^{\mathrm{VI}}{ }_{17} \mathrm{O}_{61}\right]^{10-}$ in both fresh and in $48 \mathrm{~h}$ aged solutions with $35 \%$ of free phosphate anions $\mathrm{H}_{x} \mathrm{PO}_{4}{ }^{x-3}$ and $3 \%$ remaining unidentified phosphotungstates. The ${ }^{183} \mathrm{~W}$-NMR spectra of monolacunary $\left[\mathbf{P}_{2} \mathbf{W}_{17}\right]^{10-}$ (Fig. S8A) and trilacunary $\left[\mathbf{P}_{2} \mathbf{W}_{15}\right]^{12-}$ (Fig. S8C) are in agreement with ${ }^{31} \mathrm{P}-\mathrm{NMR}$ data confirming the presence of only the monolacunary anion by 9 signals. The ${ }^{31} \mathrm{P}-\mathrm{NMR}$ spectrum of fresh hexalacunary POT $\left[\mathbf{P}_{\mathbf{2}} \mathbf{W}_{12}\right]^{12-}$ (Fig. 3D) points to the presence of unhydrolyzed hexalacunary $\left[\mathrm{H}_{2} \mathrm{P}_{2}{ }_{2} \mathrm{~W}^{\mathrm{VI}}{ }_{12} \mathrm{O}_{48}\right]^{12-}(72 \%)$ together with a low amount of monolacunary $\left[\alpha_{2}-\mathrm{P}_{2}{ }_{2} \mathrm{~W}^{\mathrm{VI}}{ }_{17} \mathrm{O}_{61}\right]^{10-}(20 \%)$. After $48 \mathrm{~h}$, the signals corresponding to hexalacunary $\left[\mathrm{H}_{2} \mathrm{P}_{2}{ }_{2} \mathrm{~W}^{\mathrm{VI}}{ }_{12} \mathrm{O}_{48}\right]^{12-}$ and monolacunary $\left[\alpha_{2}-\mathrm{P}_{2}{ }_{2} \mathrm{~W}^{\mathrm{VI}}{ }_{17} \mathrm{O}_{61}\right]^{10-}$ decreased to $9 \%$ and $3 \%$, respectively, while two intense signals at -7.5 and - $9.5 \mathrm{ppm}$ appeared. These signals are of comparable intensities, but do not correspond to the monolacunary $\left[\alpha_{1}-\mathrm{P}^{\mathrm{V}}{ }_{2} \mathrm{~W}^{\mathrm{VI}}{ }_{17} \mathrm{O}_{61}\right]^{10-}$ isomer. ${ }^{34} \mathrm{An}$ anion which can give rise to a signal at $-9.5 \mathrm{ppm}$ is $\left[\mathrm{P}^{\mathrm{V}}{ }_{2} \mathrm{~W}^{\mathrm{VI}}{ }_{19} \mathrm{O}_{69}\left(\mathrm{H}_{2} \mathrm{O}\right)\right]^{14-}$, which contains two $A-\alpha-\left[\mathrm{P}^{\mathrm{V}} \mathrm{W}^{\mathrm{VI}}{ }_{9} \mathrm{O}_{34}\right]^{9-}$ halves linked via one $\mathrm{W}^{\mathrm{VI}}$ ion in the equatorial plane and was previously reported as an intermediate species in phosphotungstate solutions as well as isolated in the solid state ${ }^{41,42}$. The signal at $-7.5 \mathrm{ppm}$ corresponds to $\left[\mathrm{P}_{8}{ }_{8} \mathrm{~W}^{\mathrm{VI}}{ }_{48} \mathrm{O}_{184}\right]^{40-}$, which was previously detected in solutions with a high amount of $\mathrm{NH}_{4}^{+37}$. The presence of four different POTs in $\left[\mathbf{P}_{\mathbf{2}} \mathbf{W}_{12}\right]^{12-} 48 \mathrm{~h}$ after preparation renders the detection of all species' signals in the ${ }^{183} \mathrm{~W}$-NMR spectrum impossible due to their low concentrations and the low abundancy (14\%) of the ${ }^{183} \mathrm{~W}$ isotope (Fig. S8D). The most intense signals at $-190.3,-191.6$ and -211.3 ppm correspond to three types of $\mathrm{W}$ ions in cyclic $\left[\mathrm{P}_{8}{ }_{8} \mathrm{~W}^{\mathrm{VI}}{ }_{48} \mathrm{O}_{184}\right]^{40-43} \cdot{ }^{31} \mathrm{P}-\mathrm{NMR}$ spectra recorded $96 \mathrm{~h}$ after preparation are identical to those recorded after $48 \mathrm{~h}$ for $\left[\mathbf{P}_{2} \mathbf{W}_{18}\right]^{6-},\left[\mathbf{P}_{2} \mathbf{W}_{17}\right]^{10-}$ and $\left[\mathbf{P}_{2} \mathbf{W}_{15}\right]^{12-}$. In the ${ }^{31} \mathrm{P}-\mathrm{NMR}$ spectrum of $\left[\mathrm{P}_{2} \mathbf{W}_{12}\right]^{12-}$, the signal at $-8.3 \mathrm{ppm}$ corresponding to hexalacunary $\left[\mathrm{H}_{2} \mathrm{P}_{2}{ }_{2} \mathrm{~W}^{\mathrm{VI}}{ }_{12} \mathrm{O}_{48}\right]^{12-}$ disappeared completely after $96 \mathrm{~h}$. In every ${ }^{31} \mathrm{P}-\mathrm{NMR}$ analysis, peaks for free phosphate were observed, indicating the release of $\mathrm{H}_{x} \mathrm{PO}_{4}{ }^{x-3}$ from the POT clusters as a consequence of partial decomposition or rearrangement (Fig. 3). The weak signals between -12 and -7 ppm in the ${ }^{31}$ P-NMR spectra (Fig. 3) with a total amount of no more than $19 \%$ of all POT signals, correspond to solution intermediates of unknown identity that have been reported previously ${ }^{44}$. The inhibitory activity of Wells-Dawson solutions does not correlate with the presence of any of those intermediates.

Influence of the substrate L-DOPA at pH 6.8 on POT's speciation. During the kinetic measurement of intact $\left[\mathbf{P}_{2} \mathbf{W}_{18}\right]^{6-}$, the solution immediately turned blue due to the intervalence charge transfer of $\mathrm{W}^{\mathrm{V}}-\mathrm{O}-\mathrm{W}^{\mathrm{VI}} \leftrightarrow \mathrm{W}^{\mathrm{VI}}-\mathrm{O}-\mathrm{W}^{\mathrm{V}}$ after addition of $L$-DOPA, hinting towards the reduction of POTs in the presence of $L$-DOPA (Fig. S18). Many POTs are redox active and can easily accept electrons ${ }^{45}$. The cyclic voltammogram of the intact Wells-Dawson anion $\left[\alpha-\mathrm{P}_{2}{ }_{2} \mathrm{~W}^{\mathrm{VI}}{ }_{18} \mathrm{O}_{62}\right]^{6-}$ displays notable proton-coupled electron redox activity, which allows this molecule to reversibly accept up to 18 electrons in aqueous solution at $\mathrm{pH} 4^{46}$. In contrast, lacunary anions (Fig. 1B-D) accept electrons less easily, for example, the reduction energy of monolacunary $\left[\alpha_{2}-\right.$ $\left.\mathrm{P}_{2} \mathrm{~W}^{\mathrm{VI}}{ }_{17} \mathrm{O}_{61}\right]^{10-}$ is less favorable by $1.6 \mathrm{eV}$ than for intact $\left[\mathrm{P}_{2}{ }_{2} \mathrm{~W}^{\mathrm{VI}}{ }_{18} \mathrm{O}_{62}\right]^{6-47}$. Since a reduction occurs only in solution of intact $\left[\mathbf{P}_{2} \mathbf{W}_{18}\right]^{6-}$ in the presence of $L$-DOPA and no color change and no change in speciation (Figs. S9, 

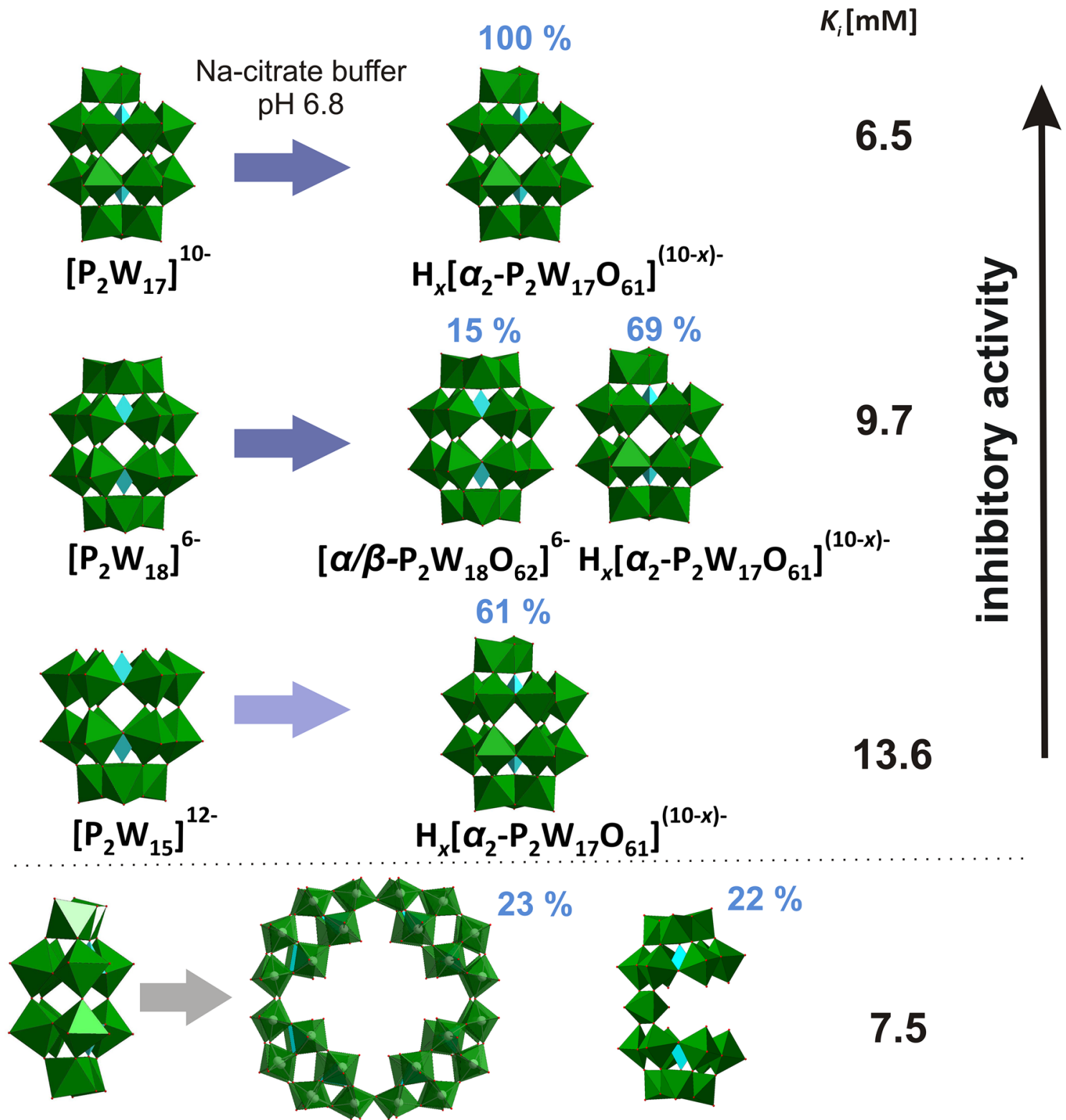

\section{5}

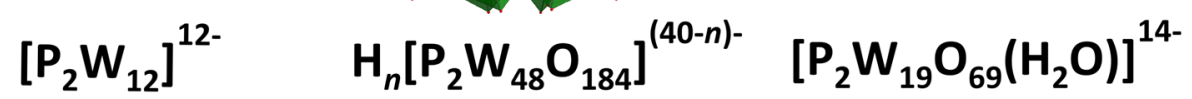

Figure 4. The POTs' inhibitory activities are compared with the main species at $\mathrm{pH} 6.8$ and at assay conditions. The intensity of the blue arrows correlates with the relative rearrangement to $\mathrm{H}_{x}\left[\alpha_{2}-\mathrm{P}_{2}{ }_{2} \mathrm{~W}^{\mathrm{VI}}{ }_{17} \mathrm{O}_{61}\right]^{(10-x)-}(x=3$ or 4) for the different inhibitors at $\mathrm{pH} 6.8$. The more $\mathrm{H}_{x}\left[\alpha_{2}-\mathrm{P}_{2}{ }_{2} \mathrm{~W}^{\mathrm{VI}}{ }_{17} \mathrm{O}_{61}\right]^{(10-x)-}(x=3$ or 4$)$ is in the sample, the higher the observed inhibitory activity of the POT. For $\left[\mathbf{P}_{2} \mathbf{W}_{12}\right]^{12-}$ two predominant species are shown. $n=7-16$ in $\mathrm{H}_{n}\left[\mathrm{P}_{8}{ }_{8} \mathrm{~W}_{48}^{\mathrm{VI}} \mathrm{O}_{184}\right]^{(40-n)-}$ according to ${ }^{58}$. Color code: $\left\{\mathrm{WO}_{6}\right\}$ octahedra, green; $\left\{\mathrm{PO}_{4}\right\}$ tetrahedra, turquoise.

S11, Table S2) were observed for the other three POT samples $\left[\mathbf{P}_{2} \mathbf{W}_{17}\right]^{10-},\left[\mathbf{P}_{2} \mathbf{W}_{15}\right]^{12-}$ and $\left[\mathbf{P}_{2} \mathbf{W}_{12}\right]^{12-}$, it can be concluded that only the intact $\left[\mathrm{P}_{2}{ }_{2} \mathrm{~W}^{\mathrm{VI}}{ }_{18} \mathrm{O}_{62}\right]^{6-}$ accepts electrons in the presence of $L$-DOPA. This reduction and protonation from $\left[\mathrm{P}_{2}{ }_{2} \mathrm{~W}^{\mathrm{VI}}{ }_{18} \mathrm{O}_{62}\right]^{6-}$ to $\mathrm{H}_{2}\left[\mathrm{P}^{\mathrm{V}}{ }_{2} \mathrm{~W}^{\mathrm{VI}}{ }_{12} \mathrm{~W}_{6}^{\mathrm{V}} \mathrm{O}_{62}\right]^{10-}$ has been previously reported at $\mathrm{pH} 6.8^{48}$. The reduction might affect inhibitory activity of $\left[\mathbf{P}_{2} \mathbf{W}_{18}\right]^{6-}$ based on the lower value of $\mathrm{R}^{2}$ for $\left[\mathbf{P}_{2} \mathbf{W}_{18}\right]^{6-}$ as compared to the ones observed for the other Wells-Dawson POTs $\left[\mathbf{P}_{2} \mathbf{W}_{17}\right]^{10-},\left[\mathbf{P}_{2} \mathbf{W}_{15}\right]^{12-}$ and $\left[\mathbf{P}_{2} \mathbf{W}_{12}\right]^{12-}($ Table 1$)$.

Charge density dependence of inhibitory effects of Wells-Dawson POT species. The charge density of POMs, expressed in number of charges $(q)$ per addenda metal ions $(m)$, is a criterion to characterize the chaotropic behavior of POMs (Table S6) ${ }^{49-53}$. Recently, it was shown that the affinity of POMs towards biomolecules is attributable to their superchaotropic character, and POMs with moderate charge densities $(q / m=0.33)$ interact considerably strong with surfaces of different or mixed polarities, which are present in protein molecules ${ }^{54}$. The activity of $\left[\mathbf{P}_{2} \mathbf{W}_{18}\right]^{6-},\left[\mathbf{P}_{2} \mathbf{W}_{17}\right]^{10-}$ and $\left[\mathbf{P}_{2} \mathbf{W}_{15}\right]^{12-}$ solutions correlates with the amount of the dominant monolacunary anion $\left[\alpha_{2}-\mathrm{P}_{2}{ }_{2} \mathrm{~W}^{\mathrm{VI}}{ }_{17} \mathrm{O}_{61}\right]^{10-}$ in Na-citrate buffer at pH 6.8 (Fig. 3, Scheme S1). 
For the unprotonated form of the active monolacunary Wells-Dawson anion $\left[\alpha_{2}-\mathrm{P}_{2}{ }_{2} \mathrm{~W}^{\mathrm{VI}}{ }_{17} \mathrm{O}_{61}\right]{ }^{10-}$ the $q / m$ ratio is 0.59 (Table 2), however, the protonation of this anion in neutral solutions has previously been shown by electrochemical analysis in combination with theoretical calculations $s^{47,55}$. For POMs the proton affinity difference between the terminal and bridging oxygen is around $11 \mathrm{kcal} \mathrm{mol}^{-156}$, proving that the four oxygen atoms surrounding the lacuna are much more basic than the bridging and terminal $\mathrm{O}$ atoms (Fig. $1 \mathrm{~B}$ ), and thus prone to protonation. Electrospray-ionization mass spectrometry (ESI-MS) has already been successfully used for the protonation states assignment of Wells-Dawson POTs containing different heteroatoms ${ }^{57}$. Consequently, ESIMS has been applied to investigate the protonation state of monolacunary $\left[\alpha_{2}-\mathrm{P}_{2}{ }_{2} \mathrm{~W}^{\mathrm{VI}}{ }_{17} \mathrm{O}_{61}\right]^{10-}$. When recording ESI-MS for POMs in Na-citrate buffer, the relative intensity of citrate anion signals is almost $100 \%$, suppressing POM signals. Hence, the measurements had to be carried out in water at $\mathrm{pH} 6.4$ (adjusted with $\mathrm{HCl}$ ), where $\left[\alpha_{2^{-}}\right.$ $\left.\mathrm{P}_{2} \mathrm{~W}^{\mathrm{VI}}{ }_{17} \mathrm{O}_{61}\right]^{10-}$ is the predominant species (Fig. S19), as well as in $\mathrm{CH}_{3} \mathrm{CN} / \mathrm{CH}_{3} \mathrm{OH} / \mathrm{H}_{2} \mathrm{O}$ mixture. The spectra recorded in both solvents show signals for $\mathrm{NaH}_{4}\left[\alpha_{2}-\mathrm{P}_{2} \mathrm{~W}_{17}^{\mathrm{VI}} \mathrm{O}_{61}\right]^{5-}$ at 838.0 and $\mathrm{NaKH}_{3}\left[\alpha_{2}-\mathrm{PV}_{2} \mathrm{~W}^{\mathrm{VI}}{ }_{17} \mathrm{O}_{61}\right]^{5-}$ at $845.6 \mathrm{~m} / \mathrm{z}$, while species with lower protonation states have not been detected (Fig. S19). Therefore, the monolacunary anion $\left[\alpha_{2}-\mathrm{P}_{2}{ }_{2} \mathrm{~W}^{\mathrm{VI}}{ }_{17} \mathrm{O}_{61}\right]^{10-}$ is present as the three-fold protonated anion $\mathrm{H}_{3}\left[\alpha_{2}-\mathrm{P}_{2}{ }_{2} \mathrm{~W}^{\mathrm{VI}}{ }_{17} \mathrm{O}_{61}\right]^{7-}$ with a charge density of 0.41 and the four-fold protonated anion $\mathrm{H}_{4}\left[\alpha_{2}-\mathrm{P}_{2} \mathrm{~W}^{\mathrm{VI}}{ }_{17} \mathrm{O}_{61}\right]^{6-}$ with a charge density of 0.35 . The predominant species in $\left[\mathbf{P}_{2} \mathbf{W}_{12}\right]^{12-}$ is the wheel-shaped $\left[\mathrm{P}_{8}{ }_{8} \mathrm{~W}^{\mathrm{VI}}{ }_{48} \mathrm{O}_{184}\right]^{40-}(23 \%)$, which can be protonated to $\mathrm{H}_{16}\left[\mathrm{P}_{8}{ }_{8} \mathrm{~W}_{48}^{\mathrm{VI}} \mathrm{O}_{184}\right]^{24-58} q / m=0.5$. Due to the compositional complexity of the hexalacunary anion it is impossible to accurately correlate its activity with the POTs' charge density.

\section{Conclusions}

The inhibitory effects of four Wells-Dawson phosphotungstates starting from intact, mono-, three- and hexalacunary forms against $A b \mathrm{PPO} 4$ were investigated with a focus on speciation under the dopachrome assay conditions. During the investigation of $\left[\mathbf{P}_{2} \mathbf{W}_{18}\right]^{6-},\left[\mathbf{P}_{\mathbf{2}} \mathbf{W}_{17}\right]^{10-}$ and $\left[\mathbf{P}_{2} \mathbf{W}_{15}\right]^{12-}$, the inhibition effect was assigned to the stable POT species $\mathrm{H}_{x}\left[\alpha_{2}-\mathrm{P}_{2}{ }_{2} \mathrm{~W}^{\mathrm{VI}}{ }_{17} \mathrm{O}_{61}\right]^{(10-x)-}(x=3$ or 4$)$, to which intact $\left[\alpha / \beta-\mathrm{P}_{2}{ }_{2} \mathrm{~W}^{\mathrm{VI}}{ }_{18} \mathrm{O}_{62}\right]^{6-}$ and trilacunary $\left[\mathrm{P}_{2}{ }_{2} \mathrm{~W}^{\mathrm{VI}}{ }_{15} \mathrm{O}_{56}\right]^{12-}$ rearrange in significant quantities (Fig. 4). Interestingly, hexalacunary $\left[\mathbf{P}_{2} \mathbf{W}_{12}\right]^{12-}$ demonstrates a more complex and time-dependent scenario with re-arrangement to the mixture of $\left[\mathrm{P}_{8}^{\mathrm{V}} \mathrm{W}^{\mathrm{VI}}{ }_{48} \mathrm{O}_{184}\right]^{40-}(23 \%)$, $\left[\mathrm{P}_{2}{ }_{2} \mathrm{~W}_{19}^{\mathrm{VI}} \mathrm{O}_{69}\left(\mathrm{H}_{2} \mathrm{O}\right)\right]^{14-}(22 \%),\left[\mathrm{H}_{2} \mathrm{P}_{2}{ }_{2} \mathrm{~W}^{\mathrm{VI}}{ }_{12} \mathrm{O}_{48}\right]^{12-}(9 \%),\left[\alpha_{2}-\mathrm{P}_{2}{ }_{2} \mathrm{~W}^{\mathrm{VI}}{ }_{17} \mathrm{O}_{61}\right]^{10-}(3 \%)$ and free phosphate $(24 \%)$, which does not allow us to unambiguously assign activity to one or several POT anions. The magnitude of the inhibitory activities correlated with the amount of $\mathrm{H}_{x}\left[\alpha_{2}-\mathrm{P}_{2}{ }_{2} \mathrm{~W}^{\mathrm{VI}}{ }_{17} \mathrm{O}_{61}\right]^{(10-x)-}(x=3$ or 4$)$ in the case of $\left[\mathbf{P}_{2} \mathbf{W}_{18}\right]^{6-}\left(K_{i}=9.7 \mathrm{mM}\right),\left[\mathbf{P}_{2} \mathbf{W}_{17}\right]^{10-}\left(K_{i}=6.5 \mathrm{mM}\right)$ and $\left[\mathbf{P}_{2} \mathbf{W}_{15}\right]^{12-}\left(K_{i}=7.5 \mathrm{mM}\right)$, which was quantified by ${ }^{31} \mathrm{P}-$ NMR peaks integration.

\section{Methods}

Protocols for synthesis, spectroscopic assignments and kinetic curves are discussed in the supplementary information. All chemicals have been purchased from Sigma-Aldrich (Vienna, Austria) and Carl-Roth (Karlsruhe, Germany) and were at least of analytical grade. They were used without further purification.

Preparation of AbPPO4 in its active form. For the preparation of active AbPPO4, the procedure published by Pretzler et al. ${ }^{15}$ was used. Briefly, latent (inactive) AbPPO4 was expressed with an N-terminal glutathione-S-transferase tag in E. coli BL21(DE3). For the protein expression, ZYM-5052 medium ${ }^{59}$ without addition of trace elements was used for $20 \mathrm{~h}$ at $20^{\circ} \mathrm{C}$, before $0.5 \mathrm{mM} \mathrm{CuSO}_{4}$ was added to the medium and incubation was continued for another $20 \mathrm{~h}$. The cells were resuspended in Tris/HCl buffer.

The cell lysis was done via French press. After centrifugation, the supernatant was loaded onto an affinity chromatography GSTrap Fast Flow column and GST-AbPPO4 was obtained after elution with glutathione. The GST tag was cut by digestion with HRV-3C protease. After another affinity chromatography step the latent $A b P P O 4$ was obtained in the flow-through. For activation of latent $A b P P O 4$ for inhibition studies the C-terminal cap was removed from the PPO with Proteinase $\mathrm{K}$ and the activated form was purified via size-exclusion chromatography in $50 \mathrm{mM} \mathrm{Na}$-citrate buffer at $\mathrm{pH} 6.8$.

Synthesis of $\alpha$-Wells Dawson POTs. The Wells-Dawson POTs were synthesized according to the procedures given in Table S2 in the Supplementary Information. The starting $\mathrm{K}_{6}\left[\alpha / \beta-\mathrm{P}_{2}{ }_{2} \mathrm{~W}^{\mathrm{VI}}{ }_{18} \mathrm{O}_{62}\right] \cdot 14 \mathrm{H}_{2} \mathrm{O}$ and $\left(\mathrm{NH}_{4}\right)_{6}\left[\alpha / \beta-\mathrm{P}_{2}{ }_{2} \mathrm{~W}^{\mathrm{VI}}{ }_{18} \mathrm{O}_{62}\right] \cdot 14 \mathrm{H}_{2} \mathrm{O}$ were synthesized as mixtures of alpha and beta isomers precisely following the procedure from ref. ${ }^{34} . \mathrm{K}_{6}\left[\alpha / \beta-\mathrm{P}_{2}{ }_{2} \mathrm{~W}^{\mathrm{VI}}{ }_{18} \mathrm{O}_{62}\right] \cdot 14 \mathrm{H}_{2} \mathrm{O}$ and $\left(\mathrm{NH}_{4}\right)_{6}\left[\alpha / \beta-\mathrm{P}_{2}{ }_{2} \mathrm{~W}_{18}^{\mathrm{VI}} \mathrm{O}_{62}\right] \cdot 14 \mathrm{H}_{2} \mathrm{O}$ are both suitable for synthesis of lacunary derivatives ${ }^{34}$. Slight modifications during the preparations are given below:

(1) $\left(\mathrm{NH}_{4}\right)_{6}\left[\alpha / \beta-\mathrm{P}_{2}{ }_{2} \mathrm{~W}^{\mathrm{VI}}{ }_{18} \mathrm{O}_{68}\right] \cdot 14 \mathrm{H}_{2} \mathrm{O}$ : During the synthesis no bromine water was added.

(2) $\left(\mathrm{NH}_{4}\right)_{12}\left[\alpha-\mathrm{H}_{2} \mathrm{P}_{2}{ }_{2} \mathrm{~W}^{\mathrm{VI}}{ }_{12} \mathrm{O}_{48}\right] \cdot 24 \mathrm{H}_{2} \mathrm{O}$ : The precipitate was collected after reaction overnight.

IR spectroscopy. A Bruker Vertex 70 IR Spectrometer equipped with a single-reflection diamond-ATR unit was used to verify the structure of the applied POTs. The distortion vibrations of W-O-W arise at 400 to $900 \mathrm{~cm}^{-1}$, the $\mathrm{W}=\mathrm{O}$ stretching vibration occurs in the range of $930-960 \mathrm{~cm}^{-1}$ and the $\mathrm{P}=\mathrm{O}$ vibrations appear between 960 and $1200 \mathrm{~cm}^{-1}$ (Fig. S6, Table S3).

Electrospray-ionization mass spectrometry. Analysis was performed with an ESI-Qq-oaRTOF supplied by Bruker Daltonics Ltd. Bruker Daltonics Data Analysis software was used to analyze the results. The measurements were carried out in $\mathrm{H}_{2} \mathrm{O}$ and in a mixture of $\mathrm{CH}_{3} \mathrm{CN} / \mathrm{MeOH} / \mathrm{H}_{2} \mathrm{O}$, collected in negative ion mode 
and with the spectrometer calibrated with the standard tune-mix to give an accuracy of better than 5 ppm in the region of $\mathrm{m} / \mathrm{z} 100-1900$.

Nuclear magnetic resonance spectroscopy. $\quad{ }^{183} \mathrm{~W}-\mathrm{NMR}$ and ${ }^{31} \mathrm{P}-\mathrm{NMR}$ were recorded with a Bruker FT-NMR spectrometer Avance Neo $500 \mathrm{MHz}$ (Bruker, Rheinstetten, Germany) at $25^{\circ} \mathrm{C}$. Chemical shifts were measured relative to $1 \mathrm{M} \mathrm{Na}_{2} \mathrm{WO}_{4}$ and $85 \% \mathrm{H}_{3} \mathrm{PO}_{4} \cdot{ }^{183} \mathrm{~W}$-NMR samples were prepared in $2.7 \mathrm{~mL}$ Na-citrate buffer $(50 \mathrm{mM}$, pH 6.8) with a POT concentration of $2 \mathrm{mM}$ with or without $1 \mathrm{mM} \mathrm{L}$-DOPA and measured in $10 \mathrm{~mm}$ tubes. The experimental time was ca. $60 \mathrm{~h}$, with a standard pulse program at $20.836 \mathrm{MHz}$ and a $63^{\circ}$ flip angle with $1 \mathrm{~s}$ relaxation delay. Subsequently, ${ }^{31} \mathrm{P}-\mathrm{NMR}$ was measured at $202.53 \mathrm{MHz}$.

${ }^{183} \mathrm{~W}-\mathrm{NMR} . \quad{ }^{183} \mathrm{~W}$-NMR was performed in $50 \mathrm{mM} \mathrm{Na}$-citrate buffer at $\mathrm{pH} 6.8$ to obtain insight into the chemical speciation and hydrolytic stability of POTs. The peaks of the ${ }^{183} \mathrm{~W}-\mathrm{NMR}$ for $\left[\mathbf{P}_{\mathbf{2}} \mathbf{W}_{18}\right]^{6-}$ are shifted by approx. 4-5 ppm downfield relative to the assignment in the literature (Table S2). The slight shifting can be explained by different buffer conditions and ionic strength of the solution with regard to the reference data.

The ${ }^{183} \mathrm{~W}$-NMR speciation indicates the presence of $\left[\alpha_{2}-\mathrm{P}^{\mathrm{V}}{ }_{2} \mathrm{~W}^{\mathrm{VI}}{ }_{17} \mathrm{O}_{61}\right]^{10-}$ anions in $\left[\mathbf{P}_{2} \mathbf{W}_{18}\right]^{6-},\left[\mathbf{P}_{2} \mathbf{W}_{17}\right]^{10-}$, $\left[\mathbf{P}_{2} \mathbf{W}_{15}\right]^{12-}$ at $\mathrm{pH} 6.8$ (Figs. S8, S12). For the ${ }^{183} \mathrm{~W}$-NMR of $\left[\mathbf{P}_{2} \mathbf{W}_{18}\right]^{6-}$ at $\mathrm{pH} 4$ two lines (1:2) were assigned (Fig. S7), whereas for the same compound at neutral $\mathrm{pH}$ a mixture of $\left[\alpha-\mathrm{P}_{2}{ }_{2} \mathrm{~W}^{\mathrm{VI}}{ }_{18} \mathrm{O}_{62}\right]^{6-}(1: 2)$ and $\left[\alpha_{2^{-}}\right.$ $\left.\mathrm{PV}_{2} \mathrm{~W}^{\mathrm{VI}}{ }_{17} \mathrm{O}_{61}\right]^{10-}(2: 2: 2: 2: 1: 2: 2: 2: 2)$ was observed (Fig. S8). Also, the $\beta$-isomer was detected at $\mathrm{pH} 4$ and $\mathrm{pH} 6.8$, respectively (Figs. S7, S8). Interestingly, the spectra for $\left[\mathbf{P}_{2} \mathbf{W}_{18}\right]^{6-}$ at $\mathrm{pH} 6.8$ with $L$-DOPA exhibits only signals for $\left[\alpha_{2}-\mathrm{P}_{2}{ }_{2} \mathrm{~W}^{\mathrm{VI}}{ }_{17} \mathrm{O}_{61}\right]^{10-}$ (Fig. S8). Upon storage of $\left[\mathbf{P}_{2} \mathbf{W}_{18}\right]^{6-}$ for $28 \mathrm{~d}$, low amounts of the $\alpha$-isomer were found, but no $\beta$-isomer was detected (Fig. S12).

${ }^{31} \mathrm{P}-\mathrm{NMR}$. The presence of $\left[\alpha_{2}-\mathrm{P}_{2}{ }_{2} \mathrm{~W}^{\mathrm{VI}}{ }_{17} \mathrm{O}_{61}\right]^{10-}$ in the ${ }^{183} \mathrm{~W}-\mathrm{NMR}$ at $\mathrm{pH} 6.8$ was confirmed by two respective signals in the ${ }^{31} \mathrm{P}-\mathrm{NMR}$ (Figs. $3, \mathrm{~S} 10$ ). The signals at 0 or higher ppm values were assigned to $\mathrm{H}_{x} \mathrm{PO}_{4}{ }^{x-3}$ $(x=1,2)$, indicating the decomposition of POTs. The signals at $-7.3 \mathrm{ppm}$ and $-14.5 \mathrm{ppm}$ were assigned to $\left[\alpha_{2}-\mathrm{P}_{2}{ }_{2} \mathrm{~W}^{\mathrm{VI}}{ }_{17} \mathrm{O}_{61}\right]^{10-}$.

Electrospray ionization mass spectrometry of AbPPO4. The mass spectrum (Fig. S2) was recorded with a LTQ Orbitrap Velos Mass spectrometer (Thermo Fisher Scientific, Bremen, Germany) fitted with a nanospray ion source, coupled to a nano HPLC-system (UltiMate 3000, Dionex), followed by deconvolution with Bruker Compass Software.

The sample was loaded on a trap column ( $\mu$-Precolumn $5 \mathrm{~mm} \times 300 \mu$ i.d. C4 PepMapp300, $5 \mu \mathrm{m}, 300 \AA$, Thermo Scientific) with $0.1 \%$ trifluoroacetic acid (TFA). The separation of the sample was implemented on a C4 analytical column $50 \mathrm{~cm} \times 75 \mu \mathrm{m}$ Accucore C4, $2.6 \mu \mathrm{m}, 150 \AA$ (Thermo Fisher Scientific) at a flow rate of 300 $\mathrm{nL} / \mathrm{min}$. Mobile Phase A consisted of $2 \% \mathrm{ACN}, 98 \% \mathrm{H}_{2} \mathrm{O}$ and $0.1 \%$ formic acid (FA). Mobile Phase B comprised $80 \% \mathrm{ACN}, 20 \% \mathrm{H}_{2} \mathrm{O}$ and $0.1 \%$ FA.

Dopachrome assay. UV-VIS measurements were carried out on a Shimadzu UV 2401PC following the specific absorption of dopachrome at $475 \mathrm{~nm}\left(\varepsilon=3700 \mathrm{M}^{-1} \mathrm{~cm}^{-17}\right)$. For all measurements, $50 \mathrm{mM} \mathrm{Na}$-citrate at $\mathrm{pH} 6.8$ was used as the buffer agent to ensure physiological conditions. The stock solutions of POTs were prepared on the day of measurements and used within 3 days.

For a general $1 \mathrm{~mL}$ reaction setup in a polystyrene cuvette, $1 \mu \mathrm{g} / \mathrm{mL} A b \mathrm{PPO} 4(\sim 23 \mathrm{nM})$ was used to catalyze the reaction. The relative inhibition was investigated using $1 \mathrm{mM} \mathrm{L}$-DOPA as the substrate and applying an inhibitor concentration range from 0 to $5 \mathrm{mM}$ to obtain activity curves. For the Lineweaver-Burk plots, a $L$-DOPA concentration range of $0.4-1.5 \mathrm{mM}$ was assayed for three different POT concentrations, respectively.

Received: 16 February 2020; Accepted: 6 August 2021

Published online: 29 September 2021

\section{References}

1. Mayer, A. M. \& Harel, E. Polyphenol oxidase in plants. Phytochemistry 18, 193-215. https://doi.org/10.1016/0031-9422(79)80057-6 (1979).

2. Mayer, A. M. Polyphenol oxidase in plants and fungi: Going places? A review. Phytochemistry 67, 2318-2331. https://doi.org/10. 1016/j.phytochem.2006.08.006 (2006).

3. Fernandez, E., Sanchez-Amat, A. \& Solano, F. Location and catalytic characteristics of a multipotent bacterial polyphenol oxidase. Pigment Cell Res. 12, 331-339. https://doi.org/10.1111/j.1600-0749.1999.tb00767.x (1999).

4. Pretzler, M. \& Rompel, A. What causes the different functionality in type-III-copper enzymes? A state of the art perspective. Inorg. Chim. Acta 481, 25-31. https://doi.org/10.1016/j.ica.2017.04.041 (2018).

5. Kampatsikas, I. \& Rompel, A. Similar but still different: Which amino acid residues are responsible for varying activities in type-III copper enzymes?. ChemBioChem 22, 1161-1175. https://doi.org/10.1002/cbic.202000647 (2021).

6. Rodríguez-López, J. N., Tudela, J., Varón, R., García-Carmona, F. \& García-Cánovas, F. Analysis of a kinetic model for melanin biosynthesis pathway. J. Biol. Chem. 267, 3801-3810 (1992).

7. Winder, A. J. \& Harris, H. New assays for the tyrosine hydroxylase and dopa oxidase activities of tyrosinase. Eur. J. Biochem. 198, 317-326. https://doi.org/10.1111/j.1432-1033.1991.tb16018.x (1991).

8. Johnson, K. A. A century of enzyme kinetic analysis, 1913 to 2013. FEBS Lett. 587, 2753-2766. https://doi.org/10.1016/j.febslet. 2013.07.012 (2013).

9. Waldrop, G. L. A qualitative approach to enzyme inhibition. Biochem. Mol. Biol. Educ. 37, 11-15. https://doi.org/10.1002/bmb. 20243 (2009). 
10. Lima, C. R. et al. Combined kinetic studies and computational analysis on kojic acid analogs as tyrosinase inhibitors. Molecules 19, 9591-9605. https://doi.org/10.3390/molecules19079591 (2014).

11. Pretzler, M., Bijelic, A. \& Rompel, A. Fungal tyrosinases: why mushrooms turn brown. In Elsevier Reference Module in Chemistry, Molecular Sciences and Chemical Engineering (ed. Reedijk, J.) (Elsevier, 2015). https://doi.org/10.1016/B978-0-12-409547-2. 11521-5.

12. Mauracher, S. G., Molitor, C., Al-Oweini, R., Kortz, U. \& Rompel, A. Latent and active $a b$ PPO4 mushroom tyrosinases cocrystallized with hexatungstotellurate(VI) in a single crystal. Acta Cryst. D70, 2301-2315. https://doi.org/10.1107/S1399004714013777 (2014).

13. Mauracher, S. G., Molitor, C., Al-Oweini, R., Kortz, U. \& Rompel, A. Crystallization and preliminary X-ray crystallographic analysis of latent isoform PPO4 mushroom (Agaricus bisporus) tyrosinase. Acta Cryst. F70, 263-266. https://doi.org/10.1107/S2053230X1 $4000582(2014)$

14. Mauracher, S. G. et al. High level protein-purification allows the unambiguous polypeptide determination of latent isoform PPO4 of mushroom tyrosinase. Phytochemistry 99, 14-25. https://doi.org/10.1016/j.phytochem.2013.12.016 (2014).

15. Pretzler, M., Bijelic, A. \& Rompel, A. Heterologous expression and characterization of functional mushroom tyrosinase (AbPPO4). Sci. Rep. 7, 1810. https://doi.org/10.1038/s41598-017-01813-1 (2017).

16. Pope, M. T. Heteropoly and Isopoly Oxometalates (Springer, 1983).

17. Gumerova, N. I. \& Rompel, A. Polyoxometalates in solution: speciation under spotlight. Chem. Soc. Rev. 49, 7568-7601. https:// doi.org/10.1039/D0CS00392A (2020).

18. Bijelic, A., Aureliano, M. \& Rompel, A. The antibacterial activity of polyoxometalates: Structures, antibiotic effects and future perspectives. Chem. Commun. 54,1153-1169. https://doi.org/10.1039/C7CC07549A (2018).

19. Bijelic, A., Aureliano, M. \& Rompel, A. Polyoxometalates as potential next-generation metallodrugs in the combat against cancer. Angew. Chem. Int. Ed. 58, 2980-2999. https://doi.org/10.1002/ange.201803868 (2019).

20. Bijelic, A. \& Rompel, A. The use of polyoxometalates in protein crystallography: An attempt to widen a well-known bottleneck. Coord. Chem. Rev. 299, 22-38. https://doi.org/10.1002/ange.201803868 (2015).

21. Bijelic, A. \& Rompel, A. Ten good reasons for the use of the Tellurium-centered Anderson-Evans polyoxotungstate in protein crystallography. Acc. Chem. Res. 50, 1441-1448. https://doi.org/10.1021/acs.accounts.7b00109 (2017).

22. Bijelic, A. \& Rompel, A. Polyoxometalates: More than a phasing tool in protein crystallography. ChemTexts 4, 10. https://doi.org/ 10.1007/s40828-018-0064-1 (2018).

23. Breibeck, J., Bijelic, A. \& Rompel, A. Transition metal-substituted Keggin polyoxotungstates enabling covalent attachment to proteinase K upon cocrystallization. Chem. Commun. 55, 11519-11522. https://doi.org/10.1039/c9cc05818d (2019).

24. Mac Sweeney, A. et al. The crystallization additive hexatungstotellurate promotes the crystallization of the HSP70 nucleotide binding domain into two different crystal forms. PLoS ONE 13(6), e0199639. https://doi.org/10.1371/journal.pone.0199639 (2018).

25. Blazevic, A. \& Rompel, A. The Anderson-Evans polyoxometalate: From inorganic building blocks via hybrid organic-inorganic structures to tomorrows "Bio-POM". Coord. Chem. Rev. 307, 42-64. https://doi.org/10.1016/j.ccr.2015.07.001 (2016).

26. Gumerova, N. I. \& Rompel, A. Interweaving disciplines to advance chemistry: Applying polyoxometalates in biology. Inorg. Chem. 60, 6109-6114. https://doi.org/10.1021/acs.inorgchem.1c00125 (2021).

27. Breibeck, J., Gumerova, N. I., Boesen, B. B., Galanski, M. \& Rompel, A. Keggin-type polyoxotungstates as mushroom tyrosinase inhibitors: A speciation study. Sci. Rep. 9, 5183. https://doi.org/10.1038/s41598-019-41261-7 (2019).

28. Briand, L. \& Baronetti, G. The state of the art on Wells-Dawson heteropoly-compounds: A review of their properties and applications. Appl. Catal. A 256, 37-50. https://doi.org/10.1016/S0926-860X(03)00387-9 (2003).

29. Gumerova, N. I. et al. Anitbacterial activity of polyoxometalates against Moraxella catarrhalis. Front. Chem. 6, 336. https://doi. org/10.3389/fchem.2018.00036 (2018).

30. Gumerova, N. I. et al. The P-type ATPase inhibiting potential of polyoxotungstates. Metallomics 10, 287-295. https://doi.org/10. 1039/C7MT00279C (2018)

31. Pimpão, C. et al. The aquaporin-3 inhibiting potential of polyoxotungstates. Int. J. Mol. Sci. 21, 2467. https://doi.org/10.3390/ijms2 1072467 (2020).

32. Hu, J.-J. et al. Transition metal substituted polyoxometalates as $\alpha$-glucosidase inhibitors. Eur. J. Inorg. Chem. 3270-3276, 2019. https://doi.org/10.1002/ejic.201900306 (2019).

33. Dawson, B. The structure of the 9(18)-heteropoly anion in potassium 9(18)-tungstophosphate, $\mathrm{K}_{6}\left[\mathrm{P}_{2} \mathrm{~W}_{18} \mathrm{O}_{62}\right] 14 \mathrm{H}_{2} \mathrm{O}$. Acta Cryst. 6, 113-126. https://doi.org/10.1107/S0365110X53000466/ (1952).

34. Ginsberg, A. P. Inorganic synthesis. Wiley Online Library 27, 104-111 (1990).

35. Müller, A. et al. „Adding“ stable functional complementary, nucleophilic and electrophilic clusters: a synthetic route to $\left.\left.\left[\left\{\left(\mathrm{SiW}_{11} \mathrm{O}_{39}\right)\right\}\right] \mathrm{Mo}_{3} \mathrm{~S}_{4}\left(\mathrm{H}_{2} \mathrm{O}\right)_{3}(\mu-\mathrm{OH})\right\}_{2}\right]^{10-}$ and $\left[\left\{\left(\mathrm{P}_{2} \mathrm{~W}_{17} \mathrm{O}_{61}\right) \mathrm{Mo}_{3} \mathrm{~S}_{4}\left(\mathrm{H}_{2} \mathrm{O}\right)_{3}(\mu-\mathrm{OH})\right\}_{2}\right]^{14-}$ as examples. Chem. Commun. 13, 1189-1190. https://doi.org/10.1039/a903170g (1999).

36. Finke, R. G., Lyon, D. K., Nomiya, K. \& Weakley, T. J. R. Structure of nonasodium - triniobatopentadecawolframatodiphosphateacetonitrile-water (1/2/23), $\mathrm{Na}_{9}\left[\mathrm{P}_{2} \mathrm{~W}_{15} \mathrm{Nb}_{3} \mathrm{O}_{62}\right] 2 \mathrm{CH}_{3} \mathrm{CN} 23 \mathrm{H}_{2} \mathrm{O}$. Acta Cryst. C46, 1592-1596. https://doi.org/10.1107/S010827019 0000038 (1990).

37. Boyd, T., Mitchell, S. G., Gabb, D., Long, D.-L. \& Cronin, L. Investigating cation binding in the polyoxometalate-super-crown $\left[\mathrm{P}_{8} \mathrm{~W}_{48} \mathrm{O}_{184}\right]^{40-}$. Chem. Eur. J. 17, 12010-12014. https://doi.org/10.1002/chem.201101666 (2011).

38. Mal, S. S. \& Kortz, U. The wheel-shaped $\mathrm{Cu}_{20}$ tungstophosphate $\left[\mathrm{Cu}_{20} \mathrm{Cl}(\mathrm{OH})_{24}\left(\mathrm{H}_{2} \mathrm{O}\right) 12\left(\mathrm{P}_{8} \mathrm{~W}_{48} \mathrm{O}_{184}\right)\right]^{25-}$ ion. Angew. Chem. Int. Ed. 24, 3777-3780. https://doi.org/10.1002/anie.200500682 (2005).

39. Copeland, R. A. Evaluation of enzyme inhibitors in drug discovery: A guide for medicinal chemists and pharmacologists. Methods Biochem. Anal. 46, 1-265. https://doi.org/10.1002/9781118540398 (2005).

40. Wang, Z.-M. et al. Rational modification of donepezil as multifunctional acetylcholinesterase inhibitors for the treatment of Alzheimer's disease. Eur. J. Med. Chem. 123, 282-297. https://doi.org/10.1016/j.ejmech.2016.07.052 (2016).

41. Maksimovskaya, R. I. \& Maksimov, G. M. ${ }^{31}$ P NMR studies of hydrolytic conversions of 12 -tungstophosphoric heteropolyacid. Coord. Chem. Rev. 385, 81-99. https://doi.org/10.1016/j.ccr.2019.01.014 (2019).

42. Tourné, C. M. \& Tourné, G. F. Aquanonadecatungstodiphosphate(14-) polyanion, $\left[\mathrm{P}_{2} \mathrm{~W}_{19} \mathrm{O}_{69}\left(\mathrm{OH}_{2}\right)\right]^{14-}: \mathrm{X}$-ray crystallographic structure of its potassium salt, chemical relationships in the tungstophosphate system, and conversion into the diaquaicosatungstodiphosphate $\left[\mathrm{P}_{2} \mathrm{~W}_{20} \mathrm{O}_{70}\left(\mathrm{OH}_{2}\right)_{2}\right]^{10-}$. J. Chem. Soc. Dalton Trans. https://doi.org/10.1039/DT9880002411 (1988).

43. Haouas, M. et al. Investigation of the protonation state of the macrocyclic $\left\{\mathrm{H}_{\mathrm{n}} \mathrm{P}_{8} \mathrm{~W}_{48} \mathrm{O}_{184}\right\}$ anion by modeling ${ }^{183} \mathrm{~W}$ NMR chemical shifts. New J. Chem. 41, 6112-6119. https://doi.org/10.1039/c7nj00915a (2017).

44. Massart, R., Contant, R., Fruchart, J. M., Ciabrini, J. P. \& Fournier, M. Phosphorus-31 NMR studies on molybdic and tungstic heteropolyanions. Correlation between structure and chemical shift. Inorg. Chem. 16, 2916-2921. https://doi.org/10.1021/ic501 $77 \mathrm{a} 049$ (1977).

45. Gumerova, N. I. \& Rompel, A. Synthesis, structures and applications of electron-rich polyoxometalates. Nat. Rev. Chem. 2, 0112. https://doi.org/10.1038/s41570-018-0112 (2018).

46. Chen, J.-J., Symes, M. D. \& Cronin, L. Highly reduced and protonated aqueous solutions of $\left[\mathrm{P}_{2} \mathrm{~W}_{18} \mathrm{O}_{62}\right]^{6-}$ for on-demand hydrogen generation and energy storage. Nat. Chem. 10, 1042-1047. https://doi.org/10.1038/s41557-018-0109-5 (2018).

47. López, X. Effect of protonation, composition and isomerism on the redox properties and electron (de)localization of classical polyoxometalates. Phys. Sci. Rev. 2, 20170137. https://doi.org/10.1515/psr-2017-0137 (2017). 
48. Sadakane, M. \& Steckhan, E. Electrochemical properties of polyoxometalates as electrocatalysts. Chem. Rev. 98, 219-237. https:// doi.org/10.1021/cr96043a (1997).

49. Assaf, K. et al. Water structure recovery in chaotropic anion recognition: high-affinity binding of dodecaborate clusters to $\gamma$-cyclodextrin. Angew. Chem. Int. Ed. 54, 6852-6856. https://doi.org/10.1002/anie.201412485 (2015).

50. Assaf, K. \& Nau, W. The chaotropic effect as an assembly motif in chemistry. Angew. Chem. Int. Ed. 57, 13968-13981. https://doi. org/10.1002/anie.201804597 (2018).

51. Buchecker, T. et al. Polyoxometalates in the Hofmeister series. Chem. Commun. 54, 1833-1836. https://doi.org/10.1039/C7CC0 9113C (2018).

52. Naskar, B., Diat, O., Nardello-Rataj, V. \& Bauduin, P. Nanometer-size polyoxometalate anions adsorb strongly on neutral soft surfaces. J. Phys. Chem. C 119, 20985-20992. https://doi.org/10.1021/acs.jpcc.5b06273 (2015).

53. Buchecker, T. et al. Self-assembly of short chain poly- $N$-isopropylacrylamid induced by superchaotropic keggin polyoxometalates: From globules to sheets. J. Am. Chem. Soc. 141, 6890-6899. https://doi.org/10.1021/jacs.8b12181 (2019).

54. Solé-Daura, A., Poblet, J. M. \& Carbó, J. J. Structure-activity relationships for the affinity of chaotropic polyoxometalate anions towards proteins. Chem. Eur. J. 26, 5799-5809. https://doi.org/10.1002/chem.201905533 (2020).

55. Asakura, T., Donnet, L., Picart, S. \& Adnet, J.-M. Extraction of hetero polyanions, $\mathrm{P}_{2} \mathrm{~W}_{17} \mathrm{O}_{61}{ }^{10-}, \mathrm{P}_{2} \mathrm{~W}_{18} \mathrm{O}_{62}{ }^{6-}, \mathrm{SiW}_{11} \mathrm{O}_{39}{ }^{8-}$ by TBP. J. Radioanal. Nuclear Chem. 246, 651-656. https://doi.org/10.1023/A:1006795929703 (2000).

56. López, X., Bo, C. \& Poblet, J. M. Electronic properties of polyoxometalates: Electron and proton affinity of mixed-addenda Keggin and Wells-Dawson anions. J. Am. Chem. Soc. 124, 12574-12582. https://doi.org/10.1021/ja020407z (2002).

57. Long, D.-L., Streb, C., Song, Y.-F., Mitchell, S. \& Cronin, L. Unravelling the complexities of polyoxometalates in solution using mass spectrometry: Protonation versus heteroatom inclusion. J. Am. Chem. Soc. 130, 1830-1832. https://doi.org/10.1021/ja075 940z (2008).

58. Baroudi, I. et al. Supramolecular assembly of gelatin and inorganic polyanions: Fine-tuning the mechanical properties of nanocomposites by varying their composition and microstructure. Chem. Mater. 27, 1452-1464. https://doi.org/10.1021/cm502605q (2015).

59. Studier, F. W. Protein production by auto-induction in high-density shaking cultures. Protein Expr. Purif. 41, 207-234. https://doi. org/10.1016/j.pep.2005.01.016 (2015).

\section{Acknowledgements}

This research was funded by the Austrian Science Fund (FWF): P27534, P32326 and P33089 (to A.R.) and P33927 (to N.I.G.) and by the University of Vienna, which is gratefully acknowledged. The authors wish to thank Anna Fabisikova, MSc for ESI-MS measurements, Ricarda Ofenschüssl and Ing. Susanne Felsinger for ${ }^{31} \mathrm{P}$ NMR measurements, Dipl.-Ing. Matthias Pretzler for valuable discussions concerning this work and Elias Tanuhadi, MSc for proofreading of the manuscript.

\section{Author contributions}

Design of the study (R.L., J.B., A.R.); conduction of the study (R.L., J.B., N.I.G.), data collection (M.S.G.), data collection, analysis, and interpretation (R.L., J.B., N.I.G.); Manuscript preparation and review (R.L., J.B., N.I.G., M.S.G., A.R.).

\section{Competing interests}

The authors declare no competing interests.

\section{Additional information}

Supplementary Information The online version contains supplementary material available at https://doi.org/ 10.1038/s41598-021-96491-5.

Correspondence and requests for materials should be addressed to A.R.

Reprints and permissions information is available at www.nature.com/reprints.

Publisher's note Springer Nature remains neutral with regard to jurisdictional claims in published maps and institutional affiliations.

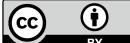

Open Access This article is licensed under a Creative Commons Attribution 4.0 International License, which permits use, sharing, adaptation, distribution and reproduction in any medium or format, as long as you give appropriate credit to the original author(s) and the source, provide a link to the Creative Commons licence, and indicate if changes were made. The images or other third party material in this article are included in the article's Creative Commons licence, unless indicated otherwise in a credit line to the material. If material is not included in the article's Creative Commons licence and your intended use is not permitted by statutory regulation or exceeds the permitted use, you will need to obtain permission directly from the copyright holder. To view a copy of this licence, visit http://creativecommons.org/licenses/by/4.0/.

(c) The Author(s) 2021 